University of Rhode Island

DigitalCommons@URI

Open Access Master's Theses

2017

\title{
A Carbohydrate Counting Intervention for Hispanics with Type 2 Diabetes
}

Flavia Cattaneo

University of Rhode Island, flaviacattaneo77@gmail.com

Follow this and additional works at: https://digitalcommons.uri.edu/theses

\section{Recommended Citation}

Cattaneo, Flavia, "A Carbohydrate Counting Intervention for Hispanics with Type 2 Diabetes" (2017). Open Access Master's Theses. Paper 1029.

https://digitalcommons.uri.edu/theses/1029

This Thesis is brought to you for free and open access by DigitalCommons@URI. It has been accepted for inclusion in Open Access Master's Theses by an authorized administrator of DigitalCommons@URI. For more information, please contact digitalcommons-group@uri.edu. 
A CARBOHYDRATE COUNTING INTERVENTION FOR HISPANICS WITH TYPE 2 DIABETES

BY

FLAVIA CATTANEO

A THESIS SUBMITTED IN PARTIAL FULFILLMENT OF THE

REQUIREMENTS FOR THE DEGREE OF

MASTER OF SCIENCE

IN

NUTRITION AND FOOD SCIENCES

UNIVERSITY OF RHODE ISLAND 


\title{
MASTER OF SCIENCE THESIS
}

OF

\author{
FLAVIA CATTANEO
}

\section{APPROVED:}

Thesis Committee:

Major Professor Geoffrey Greene

Linda Sebelia

Alison Tovar

Diane Martins

Nasser H. Zawia

DEAN OF THE GRADUATE SCHOOL

UNIVERSITY OF RHODE ISLAND

2017 


\begin{abstract}
The purpose of this study is to determine if a culturally tailored carbohydrate (CHO) counting intervention for low-income Hispanics with Type 2 Diabetes (T2DM) will increase their knowledge and skills related to $\mathrm{CHO}$ counting.

This non-experimental, single group design assessed knowledge of CHO counting in adult Hispanics with T2DM with pre- and post-surveys. Recruitment and intervention delivery were in three community locations in the Providence RI area. The intervention consisted of 3-workshops, 1-hour each, conducted in Spanish. Each workshop covered information on portion sizes guides, nutrition facts label reading, $\mathrm{CHO}$ amounts in commonly consumed foods and $\mathrm{CHO}$ counting activities. The sample was described using means and standard deviations for continuous normally distributed variables, proportion for categorical variables. Paired t-tests assessed change in knowledge. Frequency analysis described the $\mathrm{CHO}$ counting skill score. It was hypothesized that knowledge would increase and the post skills assessment score would exceed $80 \%$ indicating the mastery of the carbohydrate counting skill activity. Data were analyzed using SPSS Version 23. A probability level of $\mathrm{p}<.05$ was utilized.

Of the 42 participants that began the program, 33 finished the intervention. Average age was 62 years and 90\% were female. Participants reported an average of 6.8 years since T2DM diagnosis. The average time living in the U.S. was 25 years and $52 \%$ were from Dominican Republic. Participants had a significant increase in knowledge from pre- to post- of 2.58 points $(\mathrm{p}<.01)$ and achieved $100 \%$ of the $\mathrm{CHO}$ counting skill score at post-assessment. The program was positively evaluated at post with an average score of 4.7 out of 5 for seven evaluation questions.
\end{abstract}


The study found that low-income Hispanics with T2DM increased knowledge of $\mathrm{CHO}$ counting and demonstrated skills in $\mathrm{CHO}$ counting. This program provided an educational opportunity for low-income Hispanics with T2DM. 


\section{ACKNOWLEDGMENTS}

Writing this note of thanks is the finishing touch of my thesis. It has been a period of learning in the scientific and personal level. I would like to express the deepest appreciation to my committee members, Dr. Geoffrey Greene for his support, guidance and leadership during this research. Without his guidance, this project would not have been possible. I would like to thank Linda Sebelia for her mentorship and for all the opportunities I was given to conduct my research. Also, for granting me the opportunity for working at SNAP-Ed. Dr. Alison Tovar for her valuable guidance, knowledge and assistance. Dr. Diane Martins for her cooperation, willingness to help and expertise in the field of diabetes education.

Thank you, all my fellow graduate students, for your constant encouragement during this process. I couldn't have done without you. To all my colleagues at SNAPEd I am thankful for all your words of encouragement and support.

To my family and friends, thank you for your words of wisdom, encouragement and friendship. Lastly, I would like to thank the love of my life, David, which I only received praise and encouragement throughout the entire process. Thank you for your patience, support and love. I am forever blessed and grateful for you. I love you with all my heart. 


\section{PREFACE}

This thesis has been prepared in a manuscript format for The Diabetes Educator Journal. Manuscript format follows the magazine's manuscript guidelines for authors. The manuscript may be submitted for publications. 


\section{TABLE OF CONTENTS}

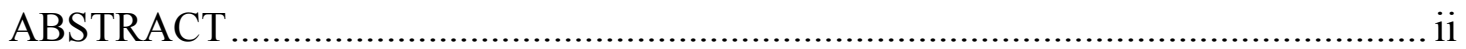

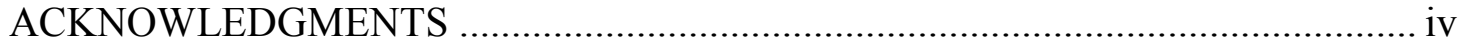

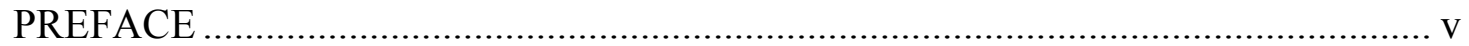

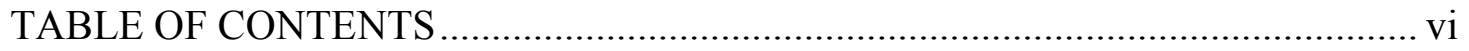

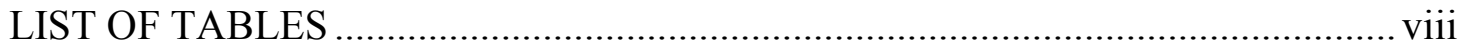

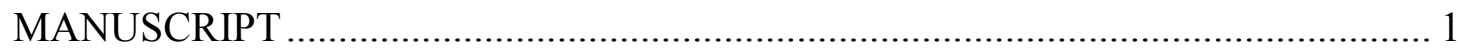

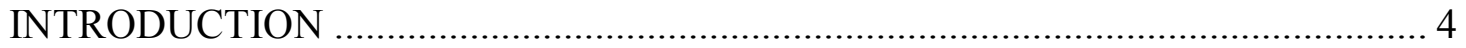

METHODOLOGY

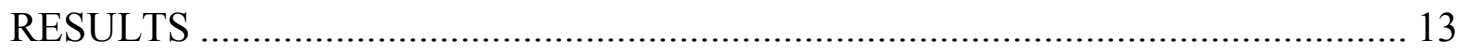

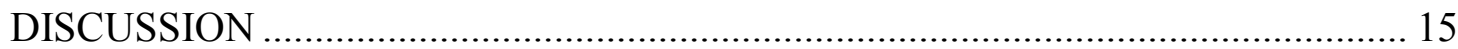

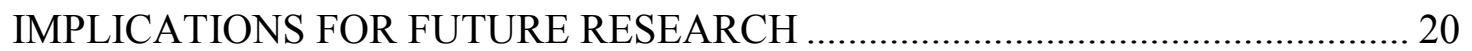

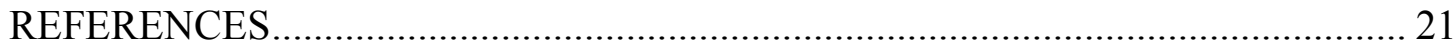

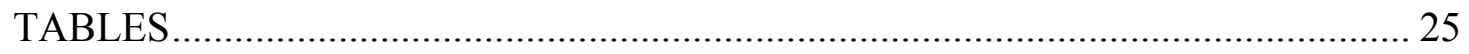

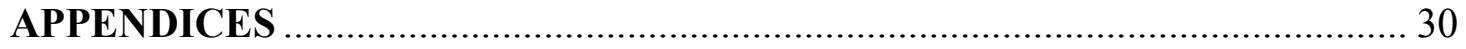

A. REVIEW OF LITERATURE................................................................. 30

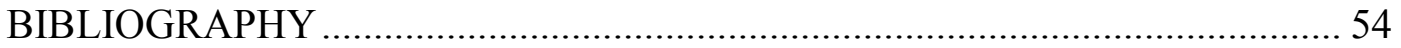

B. SIGN UP FORM-DEMOGRAPHIC, RECRUITMENT, ASSESSMENT ....... 64

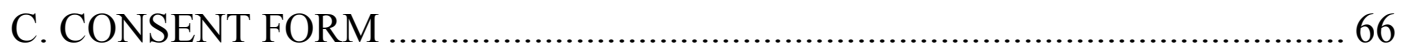

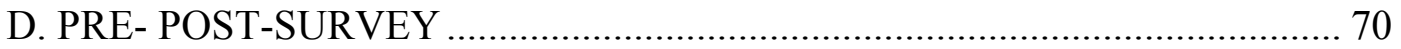

E. CARBOHYDRATE COUNTING SKILL ASSESSMENT ........................... 74

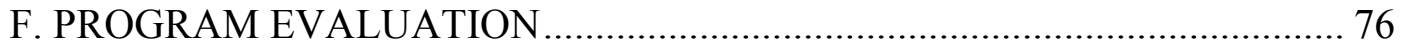

G. USDA CHOOSEMYPLATE FLYER ....................................................... 78 
H. NUTRITION FACTS LABEL FLYER ................................................. 80

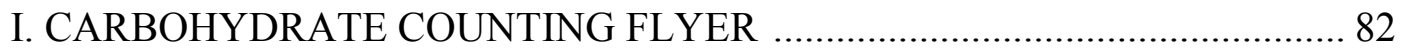

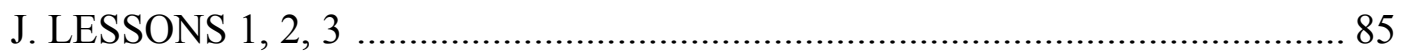




\section{LIST OF TABLES}

TABLE

PAGE

Table 1. Demographic Data of Study Participants................................................. 25

Table 2. Comparison of the Pre- Post-Test Knowledge Scores Among Study

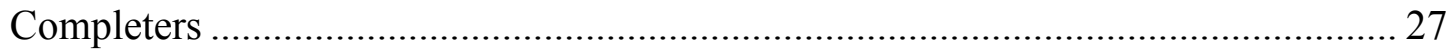

Table 3. Carbohydrate Counting Skill Test Result Among Study Completers .......... 28

Table 4. Program Evaluation Among Study Completers......................................... 29 
MANUSCRIPT

A Carbohydrate Counting Intervention for Hispanics with Type 2 Diabetes

\author{
Flavia Cattaneo ${ }^{1}$ \\ Geoffrey Greene PhD, RD, LDN ${ }^{2}$ \\ Linda Sebelia MA, MS, RD, LDN ${ }^{3}$ \\ Alison Tovar PhD, MPH ${ }^{4}$ \\ Diane Martins PhD, $\mathbf{R N}^{5}$
}

For submission to The Diabetes Educator Journal

${ }^{1}$ Department of Nutrition and Food Sciences, Fogarty Hall, University of Rhode Island, Kingston RI 02881 (flaviacattaneo@my.uri.edu)

${ }^{2}$ Department of Nutrition and Food Sciences, Fogarty Hall, University of Rhode Island, Kingston RI 02881 (gwg@uri.edu)

${ }^{3}$ Department of Nutrition and Food Sciences, Fogarty Hall, University of Rhode Island, Kingston RI 02881 (sebelia@uri.edu)

4 Department of Nutrition and Food Sciences, Fogarty Hall, University of Rhode Island, Kingston RI 02881 (alison_tovar@uri.edu)

${ }_{5}^{5}$ Department of Health and Human Services, White Hall, University of Rhode Island, Kingston RI 02881 (dcmartins@uri.edu) 


\begin{abstract}
Purpose: The purpose of this study was to determine if a culturally tailored carbohydrate $(\mathrm{CHO})$ counting intervention for low-income Hispanics with Type 2 Diabetes (T2DM) increased their knowledge related to $\mathrm{CHO}$ counting.

Methods: This non-experimental, single group design assessed knowledge of CHO counting in adult Hispanics with T2DM with pre- and post-surveys. Recruitment and intervention delivery were in three community locations in the Providence RI area. The intervention consisted of three, 1 hour-workshops, conducted in Spanish. The workshops covered information on portion sizes guides, nutrition facts label reading, $\mathrm{CHO}$ amounts in commonly consumed foods and $\mathrm{CHO}$ counting activities. Paired t-tests assessed change in knowledge and post-skill assessment score was described, in addition the average of the program evaluation items was compared to the neutral response of 3 .

Results: Of the 42 participants that began, 33 completed the program. Average age was 62 years and 90\% were female. All participants self-identified as Hispanics, reported an average of 6.8 years since T2DM diagnosis, an average of. of 25 years living in the U.S. and 52\% were from Dominican Republic. Participants increased in knowledge $(\mathrm{p}<.01)$ and $100 \%$ demonstrated $\mathrm{CHO}$ counting skill at post-assessment. The program was positively evaluated with an average score of 4.7 out of 5 which was significantly higher than 3 .

Conclusion: The study found that low-income Hispanics with T2DM increased knowledge of $\mathrm{CHO}$ counting and demonstrated skills in $\mathrm{CHO}$ counting. This
\end{abstract}


program provided an educational opportunity for low-income Hispanics with T2DM. 


\section{INTRODUCTION}

Diabetes mellitus (DM) is one of the oldest diseases of mankind. Type 2 Diabetes (T2DM) is a common form of DM characterized by hyperglycemia, insulin resistance

and relative insulin deficiency (1). In addition to genetic factors, T2DM is caused by environmental factors such as obesity, overeating, lack of exercise, stress and aging (2).

Diabetes is the leading causes of kidney failure, lower limb amputations and blindness among adults (3). There are 1.4 million new cases of DM every year and currently, 1.7 million adults have T2DM, and at least one out of three individuals will develop T2DM in their lifetime (3).

As the United States (U.S.) population rises, racial and ethnic disparities in diagnosed DM have grown as well. In 2015 the Hispanic population was the nation's largest ethnic or racial minority constituting 55 million or $17.6 \%$ of the total population (4). The Centers for Disease Control and Prevention (CDC) reported that $12.8 \%$ of Hispanics have DM, compared to $9.3 \%$ of non-Hispanics whites (5). Hispanics are $66 \%$ more likely to develop DM than non-Hispanics, and suffer disproportionately from the long-term DM related complications, including hypertension, heart disease, stroke, kidney disease, blindness, nervous system disease and lower limb amputation (6). The National Health Interview Survey and the Third National Health and Nutrition Examination Survey found that Hispanics were 50\% less likely to self-monitor blood glucose, had lower levels of leisure-time activities, consumed more carbohydrate $(\mathrm{CHO})$ and fewer vegetables, and were more likely to be overweight compared to non-Hispanics whites (7). In addition, Hispanics with DM 
encounter additional challenges to accessing health care services, including barriers of language, literacy and culture, as well as lack of transportation (8).

The Diabetes Control and Complications Trial (DCCT) found that Hemoglobin A1C (A1C) levels lower than 7\% and maintaining blood glucose levels at $80 \mathrm{mg} / \mathrm{dL}$ before meals slows the onset and progression long-term complications $(9,10)$. Diabetes self-management is key to achieve glycemic control and improving health outcomes. There is strong evidence that following a healthy diet and exercise program, taking DM medications and monitoring blood glucose improves DM outcomes (6).

Research has supported the role of $\mathrm{CHO}$ counting in the management of blood glucose (11). Proficiency in CHO counting allows increased flexibility in meal planning and increasing dietary freedom, which is an important consideration for quality of life of individuals with DM (11). Successful CHO counting depends on accurately assessing serving sizes, knowing $\mathrm{CHO}$ content of foods eaten and fitting $\mathrm{CHO}$ choices into meal plans (12). $\mathrm{CHO}$ counting has been associated with a significant reduction in A1C levels $(13,14)$ without an increase in hypoglycemic events (13). However, there are limited studies that explore $\mathrm{CHO}$ counting educational programs for Hispanics with T2DM that address the needs of this population such as language, low-literacy, limited income and culture (15).

Diabetes education plays an essential role in the self-care management of individuals. Educational programs that teach participants monitoring blood glucose, diet and $\mathrm{CHO}$ counting are important (16). Hispanics have a higher prevalence of developing T2DM than non-Hispanics, thus DM education for Hispanics are needed to 
assist this disadvantaged population (17). Fifty to $80 \%$ of the Hispanic population with DM has a significant knowledge and skill deficit related to management of DM (17). Culturally tailored DM interventions for Hispanics designed to increase knowledge of $\mathrm{CHO}$ counting are needed that address barriers such as language, low-literacy and culture (16).

The objective of this study was to assess whether low-income Hispanics would increase knowledge of $\mathrm{CHO}$ counting through a community-based $\mathrm{CHO}$ counting education program culturally tailored for Hispanics. 


\section{METHODOLOGY}

This study assessed carbohydrate $(\mathrm{CHO})$ counting knowledge in low-income Hispanics with T2DM after 3, one-hour educational sessions. The intervention used a non-experimental, single group design with a pre- and post-surveys to assess knowledge of $\mathrm{CHO}$ counting and a post- $\mathrm{CHO}$ counting skill assessment activity as primary outcomes.

\section{Sample and Locations}

The population of interest for this study was low-income Hispanics with T2DM. Inclusion criteria were self-identification as Hispanic, diagnosis of T2DM by a medical doctor, Spanish and/or English speaking with a reading comprehension level of fifth grade based on the Flesch-Kincaid Grade Level (18). Exclusion criteria included any life-threatening illness and the inability to attend all 3-sessions. Inclusion criteria were assessed by use of a sign-up form that was completed by the participants before the study began.

Participants were recruited from the RI Free Clinic, Progresso Latino and Elmwood Community Center. The Rhode Island Free Clinic, located in Providence, provides free medical care and preventive health services to low-income uninsured adults that cannot afford health services. Progresso Latino is a non-profit, community based organization in Central Falls. It provides programming to help empower Rhode Island's Latino and immigrant communities to achieve self-sufficiency and socioeconomic progress. The Elmwood Community Center supports the development of human service programs to help improve the lives of low to moderate income individuals and families in Providence. The Center provides culturally supportive 
services and programs which promote economic self-sufficiency such as a weekly food pantry.

A sign-up/assessment form was used in all three facilities for recruitment. This form facilitated the collection of demographic and disease related data for all participants. Baseline knowledge of DM was assessed by the questions, "Do you know what carbohydrates are?" and "Do you know what carbohydrate counting is?", with response categories of "Yes", "No" or "I don't Know". A consent form was also included for participants to review and sign. Recruitment was conducted as follows: At the RI Free Clinic, the researcher recruited 18 eligible participants during clinic appointment times. At Progresso Latino, the researcher recruited 14 eligible participants from existing wellness programs for Hispanics with T2DM. At Elmwood Community Center, the researcher recruited 26 eligible participants from existing programs for Hispanics as well as during food pantry hours. Promotional flyers were posted around the facilities to help with recruitment. The researcher contacted individuals to confirm participation prior to the intervention start date.

The study was approved by the University of Rhode Island Institutional Review Board.

\section{Intervention}

Prior to delivery of the three workshops, the materials and content were pilot tested with five participants at the Rhode Island Free Clinic. Pilot participants positively evaluated all aspects of the program, thus no changes were made to the lessons or materials except for one question in the pre- post-surveys. Pilot participants were not included in the study. 
The intervention was delivered at each of the community settings. The 3-one hour workshops were conducted in Spanish. All materials, sign-up and consent forms, preand post-surveys, $\mathrm{CHO}$ counting skill assessment as well as all handouts were provided in Spanish and English.

Each workshop included visuals with pictures of common Hispanic foods and portion sizes, Nutrition Facts Label of a variety of foods, and $\mathrm{CHO}$ amounts from the

food labels. There were also hands-on activities focusing on building a meal using the USDA ChooseMyPlate, reading the Nutrition Facts Labels, and CHO counting for participants to engage in. At the end of each workshop, participants practiced the skills learned and reviewed the lesson to assure comprehension. All topics in the workshops were based on SNAP-Ed's current evidence based curriculum including the Reading the Nutrition Facts Label lesson and the USDA ChooseMyPlate. The CHO counting portion of the workshops contained basic material from the American Diabetes Association (19) and Joslin Diabetes Center (20).

Educational program extenders (incentives) were provided at the end of each workshop. Examples of program extenders including measuring cups and a plastic USDA ChooseMyPlate to help with portion control. A healthy snack was provided at each workshop. The snacks were offered for the purpose of educating participants on portions sizes and to help recognize $\mathrm{CHO}$ in recipes.

\section{Instruments}

The researcher created the pre- and post-knowledge surveys consisting of ten multiple choice questions. Answers were scored as correct or incorrect and the sum of correct items was computed. Items were developed based on topics from each 
workshop because there was no validated $\mathrm{CHO}$ counting knowledge survey to use for this study. The survey was reviewed for face validity and relevance by registered dietitians, nurses and DM educators. Besides the expert review, the pilot assessed the appropriateness of the content of the questions. Participants had difficulty with the question: "Where do you find the word sugar on the Nutrition Facts Label?" That question was replaced with: "How many grams of carbohydrates do you need per snack?", with response options: 10g, 30g, 45g, 15-20g, 15g.

Participants completed the pre-survey at the start of the first workshop to assess CHO knowledge. The post-survey was completed during the third workshop. The researcher was present during assessments and read the ten questions and response categories aloud in Spanish, to assure comprehension before the participants chose their answers. By reading the questions and the answers one at a time aloud to participants, the researcher assured that the wording of each question was clearly understood. The researcher moved on to the next question once all participants had answered the current question. The survey had a literacy level of fifth grade according to the Flesch-Kincaid Grade Level (18).

Skill of CHO counting was assessed by having participants assemble a meal using the USDA ChooseMyPlate handout. Pictures of common Hispanic foods were provided including the total grams of $\mathrm{CHO}$ and portion sizes on each picture. The pictures represented three different breakfasts, three different lunches and three different dinners, and were placed into labeled plastic bags: breakfast 1, 2, 3, lunch 1, 2, 3, dinner 1, 2, 3. Participants were given a meal (a plastic bag) and asked to assemble a meal, by attaching pictures on the USDA ChooseMyPlate handout on the 
proper five food groups with $45-60 \mathrm{~g}$ of $\mathrm{CHO}$ for the meal. Participants received calculators to assist on adding the total amount of $\mathrm{CHO}$ and recorded their answers on a ChooseMyPlate recording form. $\mathrm{CHO}$ counting skill assessment calculations on the form were confirmed by the researcher before disassembling each plate. A total of 100 points were given to participants who assembled the meal between 45-60g of CHO, and 10 points was deducted for every $10 \mathrm{~g}$ above or below this range. All pilot program participants scored 100 points.

Overall program evaluation included seven questions adapted from previous SNAP-Ed evaluations: length of the program, recommend the program to a friend with DM, program met expectations, program lessons/content, presenter, handouts, overall with standard Likert-type anchored response categories ranging from strongly disagree (1) to strongly agree (5). The average of the items was calculated and compared to the neutral response (neither agree nor disagree; 3 ).

\section{Analysis}

All continuous variables were normally distributed. The sample was described by mean and standard deviation for continuous variables and proportion for categorical variables. Chi-square and t-tests compared the baseline values between program completers and non-completers. The first hypotheses, change in knowledge, was analyzed by a paired t-test. The second hypotheses, competency in $\mathrm{CHO}$ counting, was assessed by the post-assessment activity and the proportion meeting the criterion was calculated. The third hypothesis, overall program was assessed by comparing the average of the evaluation items to the neutral (3) response by paired t-test. 
Data were analyzed using SPSS Version 23 (IBM SPSS Statistics V23.0; SPSS, Inc., Chicago, IL). A probability level of $\mathrm{p}<.05$ was utilized. 


\section{RESULTS}

\section{Demographics}

A total of 42 participants began and 33 participants completed the study and nine participants did not complete the study. The overall attrition rate was $22 \%$. The characteristics of the sample are shown in Table 1. Overall, participants were predominantly female (90\%). The average participant had lived in the U.S. for 25 years. All participants spoke Spanish and were of Hispanic origin. The majority of the participants (52\%) were from Dominican Republic. The average time since DM diagnosis was 6.8 years. A total of 42 participants attended to the first workshop, 36 attended to the second workshop, and 33 attended to the third workshop.

There were no statistically significant differences between the completers and noncompleters for disease related variables except age and knowledge of $\mathrm{CHO}(p=0.03)$ and $\mathrm{CHO}$ counting ( $p=0.04$ ) based on questions completed on the sign-up/assessment form during recruitment. Completers were older $(p=0.01)$ than non-completers.

\section{Pre- and Post-Survey Scores}

Thirty-three participants completed both the pre- and post-knowledge surveys. There was an increase in knowledge between the pre- and post-surveys (3.30 \pm 1.72 to $5.88 \pm 2.08, p=0.001)($ Table 2$)$.

\section{Carbohydrate Skill Test}

A total of 33 participants completed the CHO skill test (Table 3) on the last day of the intervention. The test consisted of building a meal between $45-60 \mathrm{~g}$ of $\mathrm{CHO}$, using food pictures with total amount of $\mathrm{CHO}$ and the USDA ChooseMyPlate. All 33 
participants (100\%) successfully built a meal within target between 45 and $60 \mathrm{~g}$ of CHO exceeding hypothesized criterion of $80 \%$.

\section{Program Evaluation}

Thirty-three participants completed the 7-item program evaluation (Table 4).

Participants evaluated the program positively with the average $4.68 \pm 0.42$ which was significantly higher than neutral (3.0) $(p=0.001)$. The highest score was 4.73 on the "program overall" as well as the "length of the program". The lowest score was 4.64 on the "recommend of the program to a friend with T2DM". 


\section{DISCUSSION}

This study provided a brief nutrition intervention for low-income Hispanics with T2DM to improve knowledge and skills related to $\mathrm{CHO}$ counting. Results indicated that participants increased knowledge of $\mathrm{CHO}$ counting. At the conclusion of the study, $100 \%$ of participants demonstrated the ability to competently assemble a meal using the $\mathrm{CHO}$ counting method. In addition, participants rated the program positively. To the authors knowledge, this was the first brief intervention solely on CHO counting among low-income Hispanics delivered in Spanish at communitybased locations.

This study is similar to several studies targeting Hispanics with T2DM $(6,16,17,21-25)$. Five of these studies included educational methods designed to decrease barriers such as language, low-literacy, limited income and cultural aspects such as beliefs and mistrust as well as low socioeconomic status. However, these studies were comprehensive, in-depth, DM education programs in contrast to the current study which was a brief intervention that focused solely on $\mathrm{CHO}$ counting $(6,17,21,23,25)$. Although another study found that DM education improved blood glucose values and self-management (22); however, it did not target CHO counting. The two studies that included CHO counting with Hispanics did not show increase in knowledge of CHO counting $(16,24)$.

The sample consisted of Spanish speaking Hispanics with slightly over half from the Dominican Republic. The majority of the study sample was older adults with an average age of 62 years. The Hispanic population that attends programs at Progresso Latino and Elmwood Center programs are older adults ( $>50$ years). The age range in 
the study was similar to other studies of T2DM (26-29).

Based on the baseline knowledge questions on $\mathrm{CHO}$ and $\mathrm{CHO}$ counting, completed on the recruitment sign-up/assessment form, 37\% percent of study participants reported not knowing what $\mathrm{CHO}$ was and $60 \%$ reported not knowing what $\mathrm{CHO}$ counting was. Bishop et al. assessed CHO counting knowledge by an interviewer-administered questionnaire and found that $30 \%$ of participants with DM were not aware of the CHO counting method (30). The results of this study's baseline knowledge questions on $\mathrm{CHO}$ and $\mathrm{CHO}$ counting were supported by the pre-postknowledge surveys used in this study which included three items on $\mathrm{CHO}$ knowledge in general and six related to $\mathrm{CHO}$ counting knowledge. Among study completers $(n=33)$, on the pre-survey a total of $44 \%$ selected the correct answers on the $\mathrm{CHO}$ knowledge questions and $27 \%$ selected the correct answers for $\mathrm{CHO}$ counting. On the post-survey $62 \%$ selected the correct answers on the CHO knowledge and $68 \%$ selected the correct answers on the $\mathrm{CHO}$ counting knowledge. Although there was an increase in knowledge of 2.58 points, participants averaged $59 \%$ on the post-survey indicating continued knowledge deficits. Reasons expressed by participants for wrong answers included not having DM education before, not being seen by a DM educator such as a dietitian, nurse or pharmacist, or not fully understanding the topic since the majority never heard the term $\mathrm{CHO}$ counting before. Although two studies involving Hispanics with DM, included $\mathrm{CHO}$ counting as part of the educational program, they did not assess $\mathrm{CHO}$ counting knowledge. However these studies assessed dietary intake and found was participants showed improvements in diet adherence, including reduction of high $\mathrm{CHO}$ meals from baseline $(16,24)$. 
The CHO counting skill assessment was built using the USDA SNAP-Ed's ChooseMyPlate (31). Calculators were provided to assist with calculations and the total amount of $\mathrm{CHO}$ was printed on each picture to aid participants complete the activity. Results indicated that all participants were able to apply the material, perhaps because it was tailored to Hispanics and included familiar food pictures and visuals in Spanish. This indicates improvement in skill, as described above, most participants did not know how to count $\mathrm{CHO}$ before the intervention. Other studies included $\mathrm{CHO}$ counting skill training as part of the education, but focused on implement flexible eating and medication regimens rather than assessing knowledge of $\mathrm{CHO}$ counting skills $(12,32,33)$. To the author's knowledge, there are no studies on CHO counting skill assessment done for the Hispanic population with limited literacy.

Although eighteen participants were recruited from the Rhode Island Free Clinic, only six attended the first workshop and four finished the study. At Progresso Latino, thirteen attended the first workshop eleven finished the study. At Elmwood Center, twenty-three attended the first workshop and eighteen finished the study. The researcher called all recruited participants (58) prior to the beginning of the intervention to confirm participation, as well as followed up with participants that did not attend the first workshop. Barriers such as transportation, work hours and illness were the primary reasons for not attending. It is likely that the higher attendance at the Progresso Latino and Elmwood Center was because participants were already at the locations for prior commitments, such as all day senior care or food distribution. At the RI Free Clinic, participants had to find transportation in order to get to the location just for the DM workshops. Results are similar to other community-based studies on 
DM for Hispanics which showed low attendance at group sessions due to program length, scheduling conflicts, transportation and lack of time to commit to the study $(26,34)$.

Overall, the participants rated the program positively and reported it to be engaging and motivating. They had a positive opinion of the materials and stated they would recommend the program to a friend with DM. Positive program evaluations directly correlate to increase retention of the presented material (35).

\section{Limitations}

This study has some limitations. First, this was a non-experimental single-group study without comparison group and participants' biochemical values were not assessed due to limited resources. Another limitation was the small sample size; however, it was designed as a preliminary study to provide direction for future research in T2DM education and behavior change. The non-validated instruments were also a limitation. Even though the instruments were reviewed by experts in the DM field and assessed during the pilot, they were designed for this study and not validated. Additionally, there was a lack of hard outcomes measures, such as the A1C levels. However, previous research has found that the $\mathrm{CHO}$ counting method decreased A1C levels as well as reduced the long-term complication of DM $(22,25,36)$. Although participants showed an increase in knowledge of $\mathrm{CHO}$ counting, additional research is required to determine the long-range effects of this study on outcomes such as A1C levels.

\section{Strengths}

One of the strengths of this study is that it was culturally tailored to low-income, 
medically underserved, low-literate Hispanics with T2DM and it was delivered in Spanish by Hispanic educators. To the authors knowledge, no study has been published using the $\mathrm{CHO}$ counting method as a sole educational intervention for this population. 


\section{IMPLICATIONS FOR FUTURE RESEARCH AND PRATICE}

There is a need for studies on CHO counting interventions among low-income Hispanics with T2DM. The current study was one of the few that addressed this medically underserved population. Future studies are needed to develop and evaluate interventions and develop programs in the community that address the issues faced by Hispanics. The sample had minimal knowledge of the $\mathrm{CHO}$ counting method prior to the study. This study provided basic knowledge of foods containing $\mathrm{CHO}$ and the CHO counting method which could help improve DM self-care management. This study provided strong evidence that nutrition education intervention in the community may contribute to the DM self-care management for the limited income Hispanic population. 


\section{REFERENCES}

1. Olokoba A, Obateru O, Olokoba L. Type 2 diabetes mellitus: A review of current trends. Oman Medical Journal. 2012;10. 5001/omj.2012.68. Internet.: http://www.omjournal.org/articleDetails.aspx?coType=1\&ald=259 (accessed 2 February 2017).

2. Ozougwu J, Obimba K, Belonwu C, Unakalamba C. The pathogenesis and pathophysiology of type 1 and type 2 diabetes mellitus. J Physiol Pathophysiol. 2013;4:46-57.

3. Centers for Disease Control and Prevention. Chronic Diseases: The Leading Causes of Death and Disability in the United States. 2014. Internet: http://www.cdc.gov/chronicdisease/overview/ (accessed 2 February 2017).

4. United States Census Bureau. Hispanic Roots-Breakdown of U.S. Hispanic population. 2014. Internet: https://www.census.gov/newsroom/facts-forfeatures/2015/cb15-ff18.html (accessed 2 February 2017).

5. Centers for Disease Control and Prevention. National Diabetes Statististics Report: Estimates of Diabetes and Its Burden in the United States. 2014. Internet: https://www.cdc.gov/diabetes/pubs/statsreport14/nationaldiabetes-report-web.pdf (accessed 6 August 2016).

6. Hu J, Amirehsani K, Wallace DC, Letvak S. Perceptions of barriers in managing diabetes: perspectives of Hispanic immigrant patients and family members. Diabetes Educ. 2013;39:494-503. Internet: http://www.ncbi.nlm.nih.gov/pubmed/23640301 (accessed 4 August 2016).

7. National Health and Nutrition Examination Survey. National Health and Nutrition Examination Survey. 2011. Internet: https://www.cdc.gov/Nchs/Nhanes/Nhanes2011-2012/overview_g.htm (accessed 4 August 2016).

8. De Heer HD, Salinas J, Lapeyrouse LM, Heyman J, Morera OF, Balcazar HG. Binational utilization and barriers to care among Mexican American border residents with diabetes. Rev Panam Salud Publica. 2013;34:147-54. Internet: http://www.ncbi.nlm.nih.gov/pubmed/24233106 (accessed 4 August 2016).

9. U.S. Department of Health and Human Services. DCCT and EDIC: The Diabetes Control and Complications Trial and Follow-up Study. 2008. Internet: https://www.niddk.nih.gov/about-niddk/research-areas/diabetes/dcct-edicdiabetes-control-complications-trial-follow-up-study/Documents/DCCTEDIC_508.pdf (accessed 4 August 2016).

10. Hinzmann R, Schlaeger C.. What Do We Need beyond Hemoglobin A1c to Get the Complete Picture of Glycemia in People with Diabetes? Int J Med Sci. 2012;9:665-81.

11. Hegar K, Heiber S, Brändle M, Christ E, Keller U. Carbohydrate Counting of Food. Swiss Med Wkly. 2011;141. Internet: http://www.smw.ch/content/smw2011-13224/ (accessed 2 February 2017).

12. Gökşen D, Atik Altınok Y, Ozen S, Demir G, Darcan S. Effects of carbohydrate counting method on metabolic control in children with type 1 diabetes 
mellitus. J Clin Res Pediatr Endocrinol. 2014;6:74-8.

13. Haimoto $H$, Sasakabe $T$, Wakai K. Effects of a low-carbohydrate diet on glycemic control in outpatients with severe type 2 diabetes. Nutr Metab. 2009;6:52.

14. Son $\mathrm{O}, \mathrm{Efe} B$, Son NE, Akalin A, Kebapçi N. Investigation on carbohydrate counting method in type 1 diabetic patients. Biomed Res Int.

2014;2014:17656.

15. Rosal MC, Ockene IS, Restrepo A, White MJ, Borg A, Olendzki B, Scavron J, Candib L, Welch G, Reed G. Randomized trial of a literacy-sensitive, culturally tailored diabetes self-management intervention for low-income Latinos: Latinos en control. Diabetes Care. 2011;34:838-44.

16. Osborn $\mathrm{CY}$, Amico KR, Cruz N, Ann A, Connell O, Perez-escamilla R, Kalichman SC, Scott A, Fisher JD. A Brief Culturally Tailored Intervention for Puerto Ricans with Type 2 Diabetes. Health Educ Behav. 2011;37:849-62. Internet: http://www.ncbi.nlm.nih.gov/pmc/articles/PMC3082938/pdf/nihms271590.p df (accessed 2 August 2016).

17. González HM, Vega WA, Rodríguez MA, Tarraf W, Sribney WM. Diabetes awareness and knowledge among Latinos: Does a usual source of healthcare matter? J Gen Intern Med. 2009;24. Internet: http://www.ncbi.nlm.nih.gov/pmc/articles/PMC2764039/ (accessed 2 August 2016).

18. Flesch-Kincaid Grade Level. Readability-Score. 2011. Internet: https://readability-score.com (accessed 29 January 2017).

19. American Dianetes Association. Carbohydrate Counting. 2016. Internet: http://www.diabetes.org/food-and-fitness/food/what-can-ieat/understanding-carbohydrates/carbohydrate-counting.html (accessed 2 August 2016).

20. Joslin Diabetes Center. Diabetes and Nutrition. 2014. Internet: http://www.joslin.org/info/diabetes-and-nutrition.html (accessed 1 December 2015).

21. Duggan C, Carosso E, Mariscal N, Islas I, Ibarra G, Holte S, Copeland W, Linde S, Thompson B. Diabetes prevention in Hispanics: report from a randomized controlled trial. Prev Chronic Dis. 2014;11:E28. Internet: http://www.pubmedcentral.nih.gov/articlerender.fcgi?artid=3938962\&tool=p mcentrez\&rendertype=abstract (accessed 5 August 2016).

22. Metghalchi S, Rivera M, Beeson L, Firek A, De Leon M, Cordero-Maclntyre ZR, Balcazar $\mathrm{H}$. Improved clinical outcomes using a culturally sensitive diabetes education program in a Hispanic population. Diabetes Educ. 2008;34:698-706.

23. Wagner J, Bermudez-millan A, Damio G, Cd N, Segura-perez S, Chhabra J, Vergara C, Perez-escamilla R. Community health workers assisting Latinos manage stress and diabetes (CALMS-D): rationale, intervention design, implementation, and process outcomes. 2015. p. 415-24. Internet: https://www.ncbi.nlm.nih.gov/pmc/articles/PMC4656228/ (accessed January10 2017). 
24. Van Rompay MI, McKeown NM, Castaneda-Sceppa C, Ordovás JM, Tucker KL. Carbohydrate nutrition differs by diabetes status and is associated with dyslipidemia in Boston Puerto Rican adults without diabetes. The Journal of Nutr. 2013. p. 182-8.

25. Wheeler G, Montgomery SB, Beeson L, Bahjri K, Shulz E, Firek A, De Leon M, Cordero-MacIntyre Z. En Balance: the effects of Spanish diabetes education on physical activity changes and diabetes control. Diabetes Educ. 2012;38:72332.

26. Philis-Tsimikas, Gallo LC. Implementing community-based diabetes programs: the scripps whittier diabetes institute experience. Curr Diab Rep. 2014;14:462. Internet: https://www.ncbi.nlm.nih.gov/pmc/articles/PMC3946451/ (accessed 19 August 2016).

27. Kirk JK, Arcury TA, Ip E, Bell RA. Diabetes symptoms and self-management behaviors in rural older adults. Diabetes Res Clin Pract. 2015;107(1):54-60.

28. Rolnick SJ, Pawloski PA, Hedblom BD, Asche SE, Bruzek RJ. Patient characteristics associated with medication adherence. Clin Med Res. 2013;11:54-65. Internet: https://www.ncbi.nlm.nih.gov/pmc/articles/PMC3692389/ (accessed 1 February 2017).

29. Rosal MC, Goins KV, Carbone ET, Cortes DE. Views and preferences of lowliterate Hispanics regarding diabetes education: results of formative research. Health Educ Behav. 2004;31:388-405.

30. Bishop FK, Maahs DM, Spiegel G, Owen D, Klingensmith GJ, Bortsov A, Thomas J, Mayer-Davis EJ. The carbohydrate counting in adolescents with type 1 diabetes (CCAT) study. Diabetes Spectr. 2009;22:56-62.

31. Bailey DJ. MyPlate For My Family - SNAP Nutrition Education. 1st edition. USDA; 2014. Internet: https://choosemyplateprod.azureedge.net/sites/default/files/misc/MyPlateForMyFamilyEducatorsHandbook_MyPlateForMyFamily.pdf

32. Kawamura T, Takamura C, Hirose M, Hashimoto T, Higashide T. The factors affecting on estimation of carbohydrate content of meals in carbohydrate counting. 2015;24:153-65.

33. Mehta SN, Quinn N, Volkening LK, Laffel LMB. Impact of carbohydrate counting on glycemic control in children with type 1 diabetes. Diabetes Care. 2009;32:1014-6.

34. Johnson N. Perceived benefits and barriers to the diabetes prevention program. Plaid J. 2016. Internet: http://theplaidjournal.com/index.php/CoM/article/view/65/49 (accessed 10 January 2017).

35. Ghafoor E, Riaz M, Eichorst B, Fawwad A, Basit A. Evaluation of diabetes conversation map: education tools for diabetes self-management education. Diabetes Spectr. 2015;28:230-5.

36. Khanna A, Bush AL, Swint JM, Peskin MF, Street RL, Naik AD. Hemoglobin A1c improvements and better diabetesspecific quality of life among participants 
completing diabetes self-management programs: A nested cohort study. Health Qual Life Outcomes. 2012;10:1-7. Internet:

http://hqlo.biomedcentral.com/articles/10.1186/1477-7525-10-48 (accessed 14 February 2017). 


\section{TABLES}

Table 1. Demographic Data of Study Participants

\begin{tabular}{|c|c|c|c|c|c|}
\hline Continuous Variables & $\begin{array}{l}\text { Completer } \\
n=33\end{array}$ & $\begin{array}{l}\text { Non-completer } \\
n=9\end{array}$ & $\begin{array}{l}\text { Total } \\
n=42\end{array}$ & $t$ & $p$ \\
\hline & Mean $\pm \mathrm{SD}$ & Mean $\pm \mathrm{SD}$ & Mean \pm SD & & \\
\hline Age (Years) & $64.7 \pm 11.0$ & $52.3 \pm 17.7$ & $62.1 \pm 13.5$ & 2.62 & 0.01 \\
\hline How long live in the US (Years) & $26.1 \pm 14.1$ & $20.9 \pm 15.8$ & $24.9 \pm 14.5$ & 0.96 & 0.34 \\
\hline How long have DM (Years) & $6.9 \pm 5.5$ & $6.5 \pm 4.1$ & $6.8 \pm 5.1$ & 0.18 & 0.86 \\
\hline Pre-Test knowledge score 1 & $3.3 \pm 1.7$ & $3.3 \pm 1.8$ & $3.3 \pm 1.7$ & -0.09 & 0.92 \\
\hline Categorical Variables & $\begin{array}{l}\text { Completer } \\
n(\%)\end{array}$ & $\begin{array}{l}\text { Non-completer } \\
n(\%)\end{array}$ & $\begin{array}{l}\text { Total } \\
n=42 \\
(\%)\end{array}$ & $\chi^{2}$ & $p$ \\
\hline Gender & & & & 0.03 & 0.86 \\
\hline Male & $3(75.0 \%)$ & $1(25.0 \%)$ & $4(10 \%)$ & & \\
\hline Female & $30(78.9 \%)$ & $8(21.1 \%)$ & $38(90 \%)$ & & \\
\hline Total & $33(78.6 \%)$ & $9(21.4 \%)$ & $42(100 \%)$ & & \\
\hline \multicolumn{6}{|l|}{ Language } \\
\hline Spanish & $33(78.6 \%)$ & $9(21.4 \%)$ & $42(100 \%)$ & & \\
\hline Total & $33(78.6 \%)$ & $9(21.4 \%)$ & $42(100 \%)$ & & \\
\hline \multicolumn{6}{|l|}{ Origin } \\
\hline Hispanic & $33(78.6 \%)$ & $9(21.4 \%)$ & $42(100 \%)$ & & \\
\hline Total & $33(78.6 \%)$ & $9(21.4 \%)$ & $42(100 \%)$ & & \\
\hline Country & & & & 1.85 & 0.17 \\
\hline Dominican Republic & $18(85.7 \%)$ & $3(14.3 \%)$ & $21(52 \%)$ & & \\
\hline Puerto Rico & $2(100 \%)$ & $0(0.0 \%)$ & $2(5 \%)$ & & \\
\hline Guatemala & $2(50.0 \%)$ & $2(50.0 \%)$ & $4(10 \%)$ & & \\
\hline Colombia & $9(69.2 \%)$ & $4(30.8 \%)$ & $13(33 \%)$ & & \\
\hline Total & $312(77.5 \%)$ & $9(22.5 \%)$ & $40(100 \%)$ & & \\
\hline Had DM education & & & & 0.75 & 0.39 \\
\hline Yes & $13(72.2 \%)$ & $5(27.8 \%)$ & $18(47 \%)$ & & \\
\hline No & $13(76.5 \%)$ & $4(23.5 \%)$ & $17(45 \%)$ & & \\
\hline Don't know & $3(100 \%)$ & $0(0.0 \%)$ & $3(8 \%)$ & & \\
\hline Total & $293(76.3 \%)$ & $9(23.7 \%)$ & $38(100 \%)$ & & \\
\hline Follow DM meal & & & & 0.17 & 0.68 \\
\hline Yes & $13(76.5 \%)$ & $4(23.5 \%)$ & $17(45 \%)$ & & \\
\hline No & $13(72.2 \%)$ & $5(27.8 \%)$ & $18(47 \%)$ & & \\
\hline Don't know & $3(100 \%)$ & $0(0.0 \%)$ & $3(8 \%)$ & & \\
\hline Total & $29^{3}(76.3 \%)$ & $9(23.7 \%)$ & $38(100 \%)$ & & \\
\hline Know what $\mathrm{CHO}$ is & & & & 4.86 & 0.03 \\
\hline Yes & $13(61.9 \%)$ & $8(38.1 \%)$ & $21(55 \%)$ & & \\
\hline No & $13(92.9 \%)$ & $1(7.1 \%)$ & $14(37 \%)$ & & \\
\hline Don't know & $3(100 \%)$ & $0(0.0 \%)$ & $3(8 \%)$ & & \\
\hline Total & $29^{3}(76.3 \%)$ & $9(23.7 \%)$ & $38(100 \%)$ & & \\
\hline Know what $\mathrm{CHO}$ count is & & & & 0.04 & 0.83 \\
\hline Yes & $8(72.7 \%)$ & $3(27.3 \%)$ & $11(29 \%)$ & & \\
\hline No & $18(78.3 \%)$ & $5(21.7 \%)$ & $23(60 \%)$ & & \\
\hline Don't know & $3(75.0 \%)$ & $1(25.0 \%)$ & $4(11 \%)$ & & \\
\hline Total & $29^{3}(76.3 \%)$ & $9(23.7 \%)$ & $38(100 \%)$ & & \\
\hline
\end{tabular}




\begin{tabular}{|c|c|c|c|c|c|}
\hline Control portions & & & & 0.00 & 0.99 \\
\hline Yes & $15(75.0 \%)$ & $5(25.0 \%)$ & $20(53 \%)$ & & \\
\hline No & $12(80.0 \%)$ & $3(20.0 \%)$ & $15(39 \%)$ & & \\
\hline Don't know & $2(66.7 \%)$ & $1(33.3 \%)$ & $3(8 \%)$ & & \\
\hline Total & $29^{3}(76.3 \%)$ & $9(23.7 \%)$ & $38(100 \%)$ & & \\
\hline Read Nutrition Facts Label & & & & 0.04 & 0.84 \\
\hline Yes & $15(75.0 \%)$ & $5(25.0 \%)$ & $20(53 \%)$ & & \\
\hline No & $14(77.8 \%)$ & $4(22.2 \%)$ & $18(47 \%)$ & & \\
\hline Total & $29^{3}(76.3 \%)$ & $9(23.7 \%)$ & $38(100 \%)$ & & \\
\hline Most difficult to control DM & & & & 0.18 & 0.67 \\
\hline Blood Sugar & $13(81.3 \%)$ & $3(18.8 \%)$ & $16(50 \%)$ & & \\
\hline Diet & $12(75.0 \%)$ & $4(25.0 \%)$ & $16(50 \%)$ & & \\
\hline Total & $25^{4}(78.1 \%)$ & $7^{5}(21.9 \%)$ & $32(100 \%)$ & & \\
\hline
\end{tabular}

\footnotetext{
${ }^{1}$ Pre-test knowledge score (10 items, each correct answer worth 1 point, minimum 0 , maximum 10)

${ }^{2}$ Two completers did not provide country of origin

${ }^{3}$ Four completers did not provide answer

${ }^{4}$ Eight completers did not provide answer

${ }^{5}$ Two non-completers did not provide answer
} 
Table 2. Comparison of the Pre- and Post-Test Knowledge Scores Among Study Completers $^{6}(n=33)$

\begin{tabular}{l|rll}
\hline & Mean \pm SD & $t$ & $p$ value \\
\hline Pre-Test & $3.30 \pm 1.72$ & & \\
Post-Test & $5.88 \pm 2.08$ & & \\
Pre- \& Post-Test & $2.58 \pm 2.41$ & 6.13 & 0.001 \\
\hline$p<0.05$ & & &
\end{tabular}

\footnotetext{
${ }^{6}$ Pre-test knowledge score (10 items, each correct answer worth 1 point, minimum 0 , maximum 10)
} 
Table 3. Carbohydrate Counting Skill Test Result Among Study Completers ${ }^{7}$ $(n=33)$

\begin{tabular}{c|c}
\hline Grams of CHO & Frequency (\%) \\
\hline 45 & $8(24.3 \%)$ \\
46 & $2(6.0 \%)$ \\
47 & $2(6.0 \%)$ \\
48 & $4(12.2 \%)$ \\
49 & $1(3.1 \%)$ \\
50 & $6(18.2 \%)$ \\
51 & $3(9.1 \%)$ \\
52 & $2(6.0 \%)$ \\
56 & $2(6.0 \%)$ \\
58 & $1(3.1 \%)$ \\
60 & $2(6.0 \%)$ \\
Total & $\mathbf{3 3}^{\mathbf{8}(100 \%)}$ \\
\hline
\end{tabular}

${ }^{7} \mathrm{CHO}$ counting skill test between $45-60 \mathrm{~g}$ of $\mathrm{CHO}$

${ }^{8}$ All participants met criterion 
Table 4. Program Evaluation Among Study Completers ${ }^{9}(n=33)$

\begin{tabular}{l|c}
\hline Questions & Mean \pm SD \\
\hline The program met my expectations & $4.70 \pm 0.46$ \\
The program had useful information content & $4.67 \pm 0.48$ \\
The presenter was able to easily share the information & $4.67 \pm 0.65$ \\
The handouts given were useful and important & $4.67 \pm 0.48$ \\
Overall, how would you rate this program & $4.73 \pm 0.45$ \\
I would recommend this program to a friend with type 2 diabetes & $4.64 \pm 0.49$ \\
The length of the program was appropriate & $4.73 \pm 0.45$ \\
Average & $\mathbf{4 . 6 8} \pm \mathbf{0 . 4 2}$ \\
\hline
\end{tabular}

${ }^{9}$ Participants rated the program between strongly disagree (1) and strongly agree (5) 


\section{APPENDICES}

\section{APPENDIX A - REVIEW OF LITERATURE}

\section{Introduction}

Type 2 diabetes (T2DM) is one of the most common leading chronic medical conditions affecting millions of individuals in the United States (U.S.) (3). Diabetes (DM) has a significant impact on the health care system and is the leading cause of kidney failure, non-traumatic lower limb amputations, blindness, stroke, kidney and heart disease (3). It is estimated that $12.8 \%$ of the Hispanic population in the U.S. has been diagnosed with DM compared to $9.3 \%$ of the non-Hispanic population (37). Each year, Hispanics diagnosed with DM grows at an alarming rate of 3\% becoming an economic and social concern $(37,38)$.

It is known that the long-term complications of DM may be delayed or prevented by optimal maintenance of blood glucose control with carbohydrate $(\mathrm{CHO})$ counting (14). Controlled blood glucose levels lead to decreased A1C levels reducing the chances of developing stroke, kidney and heart disease, blindness and peripheral vascular disease leading to amputations (39). CHO counting is a meal-planning tool for individuals with DM that involves keeping track of the amount of $\mathrm{CHO}$ in the foods consumed each day (39).

Diabetes education plays an essential role in the self-care management of individuals. Educational programs that teach participants monitoring blood glucose, diet and $\mathrm{CHO}$ counting are fundamental (16). Hispanics have higher prevalence of developing T2DM than non-Hispanics, thus DM education is a key element to assist this disadvantaged population (17). In addition, the Hispanic population in the U.S. 
encounters many barriers, such as language, low literacy and cultural factors, therefore culturally tailored DM programs for this population are essential to improve quality of life (40).

This literature review explores the current literature about T2DM in Hispanics, barriers this population encounters, knowledge of $\mathrm{CHO}$ counting and efficacy of interventions/education programs for this population in the U.S.

\section{Overview of Type 2 Diabetes}

Diabetes mellitus is a metabolic disorder characterized by high concentrations of blood glucose due to partial or total failure of the pancreas to produce and secrete the hormone insulin (41). T2DM is caused by insulin resistance, which occurs when insulin is not properly utilized by the cells, therefore increasing blood glucose (41). In addition to genetic factors, T2DM is caused by environmental factors such as obesity, overeating, lack of exercise and stress, as well as aging (2). Blood tests are used to diagnosis DM because many may have no symptoms. Lab analysis of blood is necessary to ensure test results are accurate. Testing enables health care providers to find and treat DM before complications occur. Blood test levels for diagnosis of DM are hemoglobin $\mathrm{A} 1 \mathrm{C}>6.5 \%$ or above, fasting plasma glucose $126 \mathrm{mg} / \mathrm{dL}$ or above and oral glucose tolerance test $200 \mathrm{mg} / \mathrm{dL}$ or above (42). The disease course is

primarily characterized by a decline in beta-cell function and worsening insulin resistance. The process is manifested clinically by deteriorations in multiple parameters, including A1C, fasting plasma glucose (FPG), and postprandial glucose levels (43). 
It is expected that by the year of 2025, 333 million individuals around the world will be affected by T2DM (44). The 2014 National Diabetes Statistics Report by the Centers for Disease Control and Prevention (CDC) reported that from 1980 through 2014 the number of individuals with T2DM has increased from 5.5 to 29.1 million or $9.3 \%$ of the population in the U.S. $(5,45)$.

The long-term complications of DM are severe in all ages and races including retinopathy (microangiopathy affecting the capillaries of the eye), nephropathy (micro-angiopathy that affects the capillaries of the kidney), neuropathy (disease affecting nerves) and cardiovascular disease (disease of the heart and blood vessels) (9). When compared to a non-diabetic group, individuals with T2DM are 25 times more likely to become blind, 17 times more likely to develop kidney disease, 15 times more likely to require an amputation and twice as likely to experience a cerebrovascular accident (CVA) or myocardial infarction (MI) (46). Some of these complications can be monitored by recognition and response to the common symptoms of the disease. Acute and chronic symptoms that may be experienced include polydipsia (excessive thirst), hunger, polyuria (frequent urination), visual blurring, numbness and tingling in the extremities, calf pain on walking and fatigue (47).

Based on researched medical evidence by the Diabetes Control and Complications Trial (DCCT), a controlled Hemoglobin A1C (A1C) level decreases the chances of developing long-term complications of DM. The A1C blood test provides information about the individual's average levels of blood glucose over the past three months and is primarily used for DM diagnosis and management. The diagnostic 
measure for DM is when A1C is higher than 6.5\% (6). Tylee et al. studied glycemic control reflecting $\mathrm{A} 1 \mathrm{C}$ levels and reported that when patients from different treatment groups with the same A1C levels were compared, those in the conventional group had higher rates of complications. This suggests that average blood glucose levels were contributing to the long-term complications of DM (48). As with many chronic conditions, DM patients are more concerned with physical and social function, emotional and mental health, and the burden of the illness than biomarkers such as A1C, blood pressure or lipid levels (36). Quality of life measures are therefore meaningful and pertinent outcomes from patients' perspective. Khanna et. al. evaluated the relationship between diabetes-specific quality of life and A1C before and after patients completes DM self-management programs (36). The study was conducted among 50-90 year-old T2DM patients within the VA healthcare system. Patients who had A1C $>7.0 \%$ at baseline, completed two self-management programs, had A1C measurements at the VA clinic database at one-year follow-up and returned completed one-year follow-up questionnaires. Patients completed one of two DM selfmanagement programs. Programs were conducted in group settings by a DM educator, focused on DM self-management education, the importance of integrating patient selfmanagement into daily life, medications, meal preparation, portion size and control. The questionnaire assessed at one-year measured patients' quality of life including domains on DM control, anxiety and worry, social burden, sexual functioning, and energy and mobility. Out of 94 patients, a total of 75 completed the program. A1C at one-year follow-up was significantly associated with overall quality of life.

Improvements in A1C among patients completing DM self-management interventions 
were found significantly to be associated with increased quality of life on the domains described above. This study firmly stablished the relationship between improved A1C, a critical biomarker in DM, and the patient-centered diabetes-specific quality of life measure among patients completing the program (36).

\section{Type 2 Diabetes in Hispanics}

As the total population has risen in the U.S., the Hispanic population has grown as well, making it the nation's largest ethnic or racial minority constituting 55 million or $17 \%$ of the total population. (4). By 2060 , the U.S. Census Bureau projects Hispanics will constitute 119 million or $28.6 \%$ of the nation's population (4). The CDC and the American Diabetes Association reported that $12.8 \%$ of Hispanics have been diagnosed with DM, compared to $9.3 \%$ of non-Hispanics $(5,49)$. Researchers have found that Hispanic people have a higher prevalence of developing T2DM than non-Hispanic Caucasians. The risks vary considerably among this specific group and other factors, such as the length of time they have been living in the U.S., sedentary lifestyle leading to obesity, job stress independent of their lifestyle and income, low socioeconomic status including education and income $(24,26)$. Major factors of T2DM self-management include glucose monitoring, good nutrition and regular physical activity; however, Hispanics have shown poor self-management of T2DM when compared to other races $(6,7)$. The National Health Interview Survey and the Third National Health and Nutrition Examination Survey found that Hispanics were twice less likely to self-monitor blood glucose, had lower levels of leisure-time activities, consumed excessive amounts of CHOs and few vegetables, and were either 
overweight or obese (7). In addition, Hispanics with DM encounter additional challenges to accessing health care services, including language, literacy and cultural barriers, lack of transportation and geographic inaccessibility among others (51). Hu et al. explored the perceptions of barriers of managing DM among the Hispanic population with T2DM. Seventy-three adult Hispanics with T2DM identified major barriers to DM self-management such as managing the disease, lack of resources, lack of knowledge and lack of support by family members. The study was conducted in a free health clinic in central North Carolina that provides health services to a large population of low-income Hispanics. Patients diagnosed with T2DM and family members attended focus groups held in Spanish which allowed participants and their families to express their beliefs and attitudes towards barriers to DM selfmanagement. Open-ended questions were used to interview patients and their family members such as, "What is the bigger obstacle/barrier that you face in managing this disease?" and, "What is the most difficult for you?" The study revealed that Hispanics with T2DM and their family members have barriers particular to the cultural and family values of self-management of DM. Barriers perceived by both patients and family members require culturally specific understanding, clinical assessment and attentiveness by health providers, the Hispanic community and society at large. Efforts to remove barriers are important to assist this population and their families to improve their quality of life and health outcomes (6).

Osborn et al. investigated the racial and ethnic differences in self-reported DM complications among Hispanic, Black, African American, non-Hispanic, and mixed ethnicity. The study found that among 795 predominantly female participants with 
T2DM whose average age was $55,8 \%$ reported nephropathy, $35 \%$ reported retinopathy, and $16 \%$ reported cardiovascular disease. Hispanics were more likely to report having nephropathy and retinopathy, and more likely to report having cardiovascular disease than the other groups (53).

Diabetes self-management among Hispanics is inadequate, with over half of the diagnosed individuals having uncontrolled A1C levels higher than 7\% (54). In Massachusetts, adult Hispanics were recruited and randomized in a T2DM selfmanagement intervention. The study targeted 238 low-income Hispanics and consisted of a 12-week program followed by 8 -monthly sessions. The interventions targeted diabetes-related knowledge, self-efficacy and self-management behaviors, including blood glucose monitoring, diet (decreased intake and portion sizes, $\mathrm{CHO}$ control) and physical activity. The positive one-year association between glycemic index and A1C levels decreased 3\% suggesting the decrease of long-term complications of T2DM (54).

The projections report by CDC and National Health Interview Survey (NHIS) predict an increase in Hispanics with DM living in the U.S. by $111 \%$ by 2025 from five million to eleven million. The report also assume a steady, but conservative, reduction in the number of individuals with complications due to better awareness of the risks of DM, earlier screening and intervention (55).

\section{Carbohydrate (CHO) Counting}

The primary goal of DM management is to maintain blood glucose at normal levels. Many individuals with DM have A1C values that exceed the American 
Diabetes Association's (ADA) goal of 7\%, contributing to the failure to attain optimal glycemic control (56). The total amount of carbohydrates (CHOs) consumed strongly predicts glycemic response, thus, monitoring total $\mathrm{CHO}$ s by exchanges or $\mathrm{CHO}$ counting to appropriately dose rapid acting insulin is critical to lower average A1C levels and to reduce glucose variability (57). CHOs are one of the main nutrients found in food and drinks, and include sugars, starches, and fiber. $\mathrm{CHO}$ counting is a nutritional strategy that allows greater adherence to dietary management and consumption of a variety of foods for individuals with DM. Finding the right amount of carbohydrate depends on many things including how active the individual is and what, if any, medicines the individual takes. It is recommended by the American Diabetes Association that each meal contain about 45-60 grams of CHO (15 grams equals 1 serving of $\mathrm{CHO}$ ). An individual may need more or less $\mathrm{CHO}$ at meals depending how the DM is managed (58). The DCCT recommends the CHO counting method to help individuals actively manage their disease and treatment (14). The success of this method, which provides flexible eating and increases quality of life in diabetics, is dependent on the quality of the information taught by the health staff and by the amount of the time spent with the patient. It also requires vigilance on the part of the patient to maintain adequate blood glucose monitoring and the ability to determine the amount of CHOs in their meals (12).

In New Jersey, Zipp et al. assessed the impact of a $\mathrm{CHO}$ counting educational intervention on patients with $\mathrm{T} 2 \mathrm{DM}$ using the standard conversion of one $\mathrm{CHO}$ serving being equivalent to 15 grams of $\mathrm{CHO}$ (59). This experimental study was performed with ten adult participants recruited from a primary health care 
establishment. Inclusion criteria consisted of T2DM diagnosis with either insulin or noninsulin dependent. Participants received $\mathrm{CHO}$ counting education including general DM nutrition and proper use of a glucometer for self-monitoring blood glucose levels. This was conducted by a registered dietitian and certified DM educator. During the 3-month period, participants kept a daily fasting log, preprandial and postprandial blood glucose levels, along with the number and types of $\mathrm{CHOs}$ consumed for breakfast, lunch, dinner and two snacks. The study reported that participants improved their A1C levels by $1 \%$ at a 12 -month follow-up. It also revealed that participants felt empowered and motivated to take control of their DM. Thus, education on $\mathrm{CHO}$ counting impacts $\mathrm{A} 1 \mathrm{C}$ levels and may influence long-term DM complications (59).

Son et al. investigated the effects of the $\mathrm{CHO}$ counting method on the quality of life as well as the success of the treatment in diabetic patients (14). A registered dietitian trained twenty-two patients in the $\mathrm{CHO}$ counting method; fifteen patients receiving a standard diabetic diet were the control group and all patients were monitored for six months. Patients in the $\mathrm{CHO}$ counting group learned about the amounts of $\mathrm{CHO}$ in foods, the effects of protein, fiber, and fat on $\mathrm{CHO}$ absorption. Patients were monitored by continuous communication with the doctor and the dietitian from whom they learned the $\mathrm{CHO}$ counting method and were asked to apply the method on their own. At six months of treatment, the frequency of hypoglycemia decreased in the $\mathrm{CHO}$ counting group while it increased in the control group. In the $\mathrm{CHO}$ counting group, the 6-month data revealed a favorable trend in all variables indicating an increased quality of life while there was no statistically significant 
increase in the control group. Son et al. suggested that, when applied to motivated patients, the $\mathrm{CHO}$ counting method might prevent excessive food consumption via prevention of frequent hypoglycemic attacks, thus, also contributing to weight loss. The study also indicated that the quality of life was increased in the $\mathrm{CHO}$ counting group as compared to the control group (14).

The $\mathrm{CHO}$ counting method is not a new approach. There is data indicating that this method has been applied in the nutritional plan of the diabetic patients since 1921 when insulin was discovered. However, the interest in this method has increased along with the use of insulin pumps and insulin analogues. The $\mathrm{CHO}$ counting method that offers a flexible eating regimen to diabetic individuals is a functional method to render the patient more conscious and active about the disease and treatment (60). Clinical studies shown that CHOs are the main factor that affects the postprandial blood glucose level and determines the need of insulin. CHOs are transformed into glucose two hours after ingestion and enter into circulation in the first fifteen minutes; postprandial glycemic response and the need of insulin are determined by the total $\mathrm{CHO}$ amount that is ingested rather the type of $\mathrm{CHO}$ (14).

CHO counting is a suitable solution for many individuals with DM, making it easier to fit a wide variety of foods into the meal plan. It can also control blood glucose, decreasing A1C levels and overtime minimizing the long-term complications of DM.

Interventions and Educational Programs for Hispanics with T2DM 
Nutrition education interventions promoting dietary change have shown to have positive effects on behavior, thus reducing the chronic disease burden (61). During the past decade, various interventions have been designed, implemented and replicated with varying degrees of success. In order to make interventions available to minority groups, researchers and program developers have adapted and tailored existing programs for use with low-income minority communities. Cultural adaptations ideally should involve modifications like language and ethnically matched providers, and also consider cultural characteristics, including acculturation levels, values, traditions and practices $(62,63)$.

In the Cultural Adaptation of a Nutrition Education study in San Diego, Broyles et al. explained how an existing nutrition education program was adapted for Hispanic families, and reported indicators of its acceptability (63). Several components were considered including bilingual and bicultural educators, material translation of handouts and recipes, and structure characteristics of culture such as common values and cultural mealtime practices. During 27 months, 974 families participated in one or more group classes. Classes topics included the increased access to traditional foods like fruits and vegetables, the use of simple additions or affordable modifications that could improve nutritional value, and the reinforcement of the Hispanic cultural practice of preparing meals at home and eating together as a family. Classes were held over a 10 -week period and $68 \%$ completed the entire program. Barriers to the participants' inability to attend the program included moving, new job, giving birth and family illness. The positive outcome of this study were changes in knowledge, behaviors and self-efficacy for parents and well as for their children. Examination of 
pre- and post-survey data generated statistically significant positive changes in knowledge showing $71 \%$ of the questions on the post-survey compared to $28 \%$ on the pre-survey. However, this process required several months of piloting and refining materials and program delivery. It is believed that the program disparity was reduced because of input from the local community based program partners, assistance from family educators and professionals from Hispanic communities who guided the program design and delivery (63).

Lifestyle interventions can prevent T2DM in at risk populations by improving glycemic control (21). Interventions can be successful in one racial or ethnic group, but may not be generalized to others because of specific cultural or economic barriers. In Washington State, Hispanics aged 18 or older were recruited at health fairs and local community events held from 2008 to 2012. A total of 111 Hispanics with T2DM participated in 5-guided educational sessions once-per-week, led by bilingual Hispanic Community Health Workers trained in DM education. Each session involved DM education and awareness, and methods to increase self-management of the disease. Session topics were general DM, self-management, diet including CHO counting, physical activity and complications of DM. The curriculum was distributed by a set of flip charts developed by investigators with input from the community, revised and translated to Spanish. The study demonstrated a significant reduction in A1C of $0.64 \%$ from baseline to 3-month period. There was no significant change in fruit and vegetable consumption or on frequency of leisure time physical activity. Duggan et al. reported that the success of the study was due to the removal of barriers such as 
language. With bilingual workers, participants showed high program satisfaction and interest, and made one positive behavior change as a result of the intervention (21).

Efforts are needed to improve the effectiveness and accessibility of DM education programs that would reduce or eliminate the barriers for ethnic low-income groups. Health behavior change interventions are more effective when the content is specific to a health behavior and relevant to the appropriate population (64). Osborn et al. described the importance of integrating health behavior change theory and culturally tailored content in the design of DM self-management education, as well as improving the availability in clinical and community-based settings (64). Diabetes education programs need to address the variations in cultural values underlying motivations, preferences and behaviors of individuals from ethnic groups by using approaches that are adapted to the targeted group. Such approaches have shown promise in increasing physical activity and improving eating habits among ethnic minority low-income groups and may translate into similar advantages for DM self-management education programs (64). The extent to which these programs are effective or not among ethnic low-income minority groups outside these settings has received less attention, making it particularly difficult to address population-specific barriers to behavior change. Researchers are beginning to fill in these gaps in the literature. This is essential for designing more effective DM self-management education programs that address population-specific determinants of behavior change, therefore removing barriers for ethnic low-income groups (64).

The Hispanic communities in the U.S. have the poorest access to care and the lowest use of health services. An estimated $32 \%$ of Hispanics living the U.S. do not 
have health insurance compared to $15 \%$ of the non-Hispanics groups. Besides economic limitations, they face additional barriers to accessing health services including language, literacy levels, lack of transportation and geographic inaccessibility (65). "Barriers to Care and Comorbidities Along the U.S.-Mexico Border" was conducted in El Paso, Texas at the U.S.-Mexico border where about 80\% of residents are Hispanics. The primary goal was to compare barriers to health care of participants with and without comorbidities. A household survey was conducted from November 2009 to May 2010. Households were selected based on geography and population density. A total of 1,002 households were recruited, selected and interviewed. In all, $37.7 \%$ of households reported two or more comorbidities, hypertension and DM being the highest at $9.7 \%$ of the participants. Financial barriers to attaining health care were the most commonly reported barriers for those without comorbidities; $72.6 \%$ of participants reported that paying $\$ 100$ for medical care would be difficult. Transportation barriers were mentioned least frequently among people without comorbidities at 5.9\%. Cognitive barriers were common ranging from confusion about the arrangements in medical settings or about medical information, difficulty understanding medical information instructions, and not always being treated with respect (65). Intervention studies to address chronic conditions among Hispanics require the consideration of the greater burden of medical care. When implementing cultural interventions by using community outreach strategies, it is essential to consider the high proportion of Hispanics who have high rates of comorbidities (65). 
Language preference and English language proficiency have previously been associated with health-related behaviors, disease prevalence, and receipt of health care services among Hispanics (66). Barriers to the achievement of treatment goals include language, cost and access to proper health services. Hispanics patients with T2DM are less likely to receive appropriate T2DM quality of care. They are less likely to selfmonitor their disease. In addition, they are less likely to have their feet and eyes examined by a health care problem. Evidence suggests that the use of culturally sensitive education programs can improve T2DM outcomes in the Hispanic population. With greater healthcare provider awareness and wider availability of programs tailored to Hispanics, the current treatment gap among ethnic minorities in the U.S. will progressively narrow, and hopefully vanish (67).

Several multidisciplinary approaches to treat T2DM, such as educational interventions, goal settings, blood glucose self-monitoring, and nutrition education have been well documented demonstrating improvements in glycemic control and other T2DM outcomes. However, minimal practice-based research exists that directly shows the benefit of intense nutrition education with a focus on $\mathrm{CHO}$ counting to improve T2DM outcomes $(59,68)$. Osborn et al. conducted a study in Spanish for Hispanics with T2DM (16). Within the Hispanic population, language differences between individuals delivering the health information and those receiving it, has contributed to barriers and have been thought to promote misinformation about DM self-management. The lack of information has also been documented in this study, including the lack of knowledge of what foods are nutritionally appropriate or that CHO counting, as well as glycemic control, is a critical component to a healthy diet. 
Participants were recruited from an outpatient primary care clinic in Connecticut. A total of 118 Hispanics participated in the study, completed a baseline assessment and were randomized into an intervention or control group. The intervention group completed baseline and follow-up assessments that took place within five days and the control group completed assessment including nutrition education, medical treatment, and optional DM support. All didactic education was delivered in Spanish by a Registered Dietitian and Certified Diabetes Educator (CDE) also of Hispanic heritage. The intervention was a 90-minute single session that allocated 60 minutes to diet content and 30 minutes to food label reading and diet adherence. Follow up occurred at three months post intervention. One of the most important measures was the $\mathrm{CHO}$ counting which participants exercised in how to read food labels, how to measure portion sizes of foods, how to select foods that were low or high in CHOs and how to count the CHOs in foods. Overall, the intervention incorporated the language, customs, attitudes, perceptions and behaviors of the target population. In addition, all educational materials were available in Spanish and English, and all recommendations incorporated culturally familiar foods. Findings suggested that A1C levels decreased from baseline $(0.48 \%)$, and the participants showed improvement in knowledge in a short period of time. Yet, the notion that a 90-minute intervention maybe more effective when including follow-ups over an extended period of time is promising (16). Despite the lack of data on Hispanic populations and cultural appropriate nutrition education, it is clear that in addition to emphasizing nutrition, effective T2DM programs need to include a strong $\mathrm{CHO}$ counting component, and need to assure that these programs are culturally responsive by including program content that 
is based on cultural preferences and addresses lower levels of English proficiency, especially if they involve recent immigrant Hispanics (22). The En Balance study was designed to assess the feasibility of culturally and language-sensitive T2DM education as a way to increase physical activity and to improve T2DM management in a group of Spanish-speaking Hispanics in the Southern California (25). This was a 3-month study to test the impact of Spanish language comprehensive DM education program in Hispanics with T2DM. Primary outcomes were changes in blood glucose values, A1C values, weight reduction and physical activity. Study phases included recruitment, baseline data collection, DM education and collection of data at the end of the threemonth educational process. A total of 39 participants completed the three-month study. Participants attended evening DM education classes delivered by registered dietitians, nurses, physicians and Hispanic students from the School of Public Health. The En Balance DM education program demonstrated that culturally sensitive DM education that stresses nutrition and exercise can lead to improvements in glucose control and physical activity. Following the 3-month intervention, there was a statistically significant reduction in mean A1C. This finding is consistent with other programs deemed culturally competent for the Hispanic population in terms of language, diet, social emphasis and incorporation of cultural health beliefs. This study demonstrated the effectiveness of culturally sensitive DM education in the community as a method for gaining control of blood sugar control and increasing physical activity (25).

Nutrition education, as an essential aspect in the treatment of diabetic patients, has been on-going since 1975. Its importance has been shown in communities with 
different socioeconomic and cultural levels. Diabetes education requires training, knowledge, education skills, communication, listening abilities, and understanding from the health care team. The need to develop health education practice activities for diabetic patients is associated with the prevention of complications of the disease through self-management, allowing patients to live better with the disease. Diabetes self-management is the process of teaching patients to take control of the disease. The goals in DM education consist of improving metabolic control, preventing acute and chronic complication and improving the quality of life of individuals at reasonable costs. Among the Hispanic population, there is a significant knowledge and skill deficit between 50 to $80 \%$ of this population. Less than half of the individuals are able to monitor blood glucose. Culturally tailored DM interventions are needed that are both grounded in behavior change theory and focus on other high risk racial/ethnic minorities with DM $(69,70)$. There is clinical evidence supporting current DM treatment methods, but a set of studies designed to help minority Hispanics is not as strong. More research is needed to close the quality gap and reduce the impact of this pervasive health threat (71).

\section{Nutrition Education in the Community}

The U.S. Department of Health and Human Services Office on Minority Health reports the minority communities bear a disproportionally high burden of major nutrition-related chronic diseases (72). Obesity, T2DM, cardiovascular disease and some forms of cancer are costly and are associated with substantial morbidity, mortality and a reduced quality of life. Diet and nutrition are critical factors in the 
prevention and control of these diseases, therefore having an important role in nutrition-related interventions (72). Remarkable progress has been made in managing DM and its complications. Because of public health efforts, a higher percentage of individuals with DM are monitoring blood glucose daily and receiving annual foot and eye exams. The incidence of treatment for diabetes-related end-stage renal disease declined 21\% from 1997 to 2002 and the prevalence of visual impairment decreased from $24 \%$ in 1997 to $18 \%$ in 2005 . Yet, DM diagnosis is increasing and if current trends continue, by 2050, one in three adults in the U.S. could develop DM during their lifetime (73). Evidence indicates that with education, social support and healthy policies, individuals can and will take charge of their health. Strategies are needed to facilitate and support individual responsibility and behavior change at schools, workplaces, community, and medical based settings. Doctors need more community based programs to refer patients to once a condition has been detected. Communitybased programs such as those that prevent and educate individuals with DM, hypertension management and tobacco cessation are necessary and needed (73).

Traditional treatment strategies that focus on medication alone are not enough to achieve normal blood glucose levels among Hispanics (74). Limited English proficiency often leads to communication barriers between the healthcare providers and Hispanics patients. Lack of provider cross-cultural communication skills to address cultural values among Hispanics may result in dissatisfaction and delay some from seeking medical help. Medical education and support delivered in a community setting by well-trained and supervised, bilingual community health workers who 
understand the community's social determinants of health are likely to improve T2DM among Hispanics $(22,74)$.

The U.S. Department of Agriculture (USDA) promotes behavior that can reduce the impact of the obesity epidemic among low-income populations through its Supplemental Nutrition Assistance Program-Education (SNAP-Ed) program, which is designed to increase nutritious food choices through nutrition programs offered in community settings (75). Molitor et al. investigated the external validity of SNAP-Ed nutrition interventions as implemented by organizations in California. Surveys from eligible adults SNAP-Ed individuals reported that participants (59.6\%) were Hispanics (75). Higher levels of intervention directly correlated to healthier eating habits than in the low- to no-reach census tracts. The greatest concentration of SNAP-Ed interventions was related increasing consumption of fruits and vegetables and reducing fast food intake. These interventions can play an important role in addressing the obesity and T2DM epidemic in the U.S. (75). SNAP-Ed programs, across the lifespan, have the potential to improve nutrition behaviors among low-income individuals (76).

Improving the delivery of nutrition education to patients in community settings is essential to improving population health in an era where increasing chronic diseases related to aging, obesity and lifestyle contribute dramatically to public health challenges and associated health care costs. There is an urgent need to better prepare health care professionals to address nutrition-related conditions using best practices. This will require dietitians and nutrition professionals to assume leadership roles in the training of health care professionals (77). Intensive lifestyle interventions are an 
effective T2DM prevention strategy in patients at high risk for the disease. In addition to reducing the incidence of T2DM, these interventions can delay or prevent the development of complications of the disease (78). Studies aimed at interpreting research-based prevention programs into clinical and community-based practice, and examining cost-effective and original means of delivering prevention are also necessary. Due to the size and trajectory of DM, the potential benefits that could result from prevention strategies are massive. The ADA's support for research and programs extends beyond the clinical setting. There is the need to increase awareness, address behavioral and environmental barriers and disparities in the community where people work and live. Unlike clinical settings, where time, support, and access are often limited, community-based programs can provide culturally and age-appropriate education and tools designed to delay and/or prevent the onset of DM, or reduce risks of its complications (79).

\section{Conclusion}

The prevalence of DM in the U.S. is 29 million people or $9.3 \%$ of the population (37). Hispanics are at higher risk for T2DM than non-Hispanics (50). The U.S. Census Bureau estimates that by 2050, 1-in-3 adults living in the U.S. will be of the Hispanic origin, which may lead to an increase in the number of T2DM diagnoses (50).

Individuals with T2DM have a greater chance of developing a variety of complications and health problems, especially if blood glucose, blood pressure and cholesterol are not well managed. The long term complications of T2DM are eye complications, as cataracts and glaucoma result in vision loss; foot problems such as wounds that will not heal due to DM affecting blood flow to the feet; nerve problems 
(peripheral neuropathies) reducing blood circulation to nerves that may damage and cause numbness; kidney disease which affects removed waste products, excess nutrients and fluid from the body via small vessels (46).

The A1C test is the primary test used for DM management and research. It measures the average levels of blood glucose over the past three months. Diagnosis of $\mathrm{DM}$ is when $\mathrm{A} 1 \mathrm{c}$ is $6.5 \%$ or above. The higher the $\mathrm{A} 1 \mathrm{C}$ (above $7 \%$ ), the higher the chances for developing the long-term health problems caused by consistently high blood glucose levels. Studies have demonstrated substantial reductions in long-term complications with the lowering of A1C levels (80).

For most ethnic minority groups, discussion of cultural dynamics in health care cannot take place without consideration of the ways which culture interconnects with issues of poverty and equity, including access and utilization to health care and the lack of cultural competence on the part of health providers and programs. Hispanics face many barriers when it comes to assessing health care, including service availability, accessibility, acceptability, as well as culturally barriers, low literacy and language barriers, income and socioeconomic barriers. These barriers need to be addressed in order to properly educate Hispanics living with T2DM in the U.S. It is important to profile this population, who are limited in income and literacy living with T2DM and to investigate the many components of DM self-management (81).

$\mathrm{CHO}$ counting is a tool that helps patients to estimate the amount of $\mathrm{CHOs}$ of meals in order to minimize the glucose increase after a meal, and if necessary, to correct either high or low blood glucose levels. Research studies have demonstrated interventions involving $\mathrm{CHO}$ counting help to improve $\mathrm{A} 1 \mathrm{C}$ levels thereby, decreasing 
the risks of long-term DM complications. $\mathrm{CHO}$ counting is associated with reduction of A1C not accompanied by an increase of hypoglycemic events (82). However, there are limited studies that explore $\mathrm{CHO}$ counting educational programs for Hispanics with T2DM that address the needs of this population such as language, low-literacy, limited income and culture.

Diabetes education has been shown to improve behaviors and quality of life of individuals with T2DM. Educational components include nutritional management, physical activity, medications, glucose monitoring and psychosocial adjustment. Community nutrition DM education can help patients take control of DM by making necessary changes which improve lifestyle. Community DM education programs must offer accessible information and support throughout the community and must be delivered in a format in which low-income minority groups are able to understand and apply the information on a daily basis. Community programs lower barriers and clarify myths related to cultural beliefs in DM management and ultimately improve patient internal locus of control, which is defined as the patient's perception that the individual can make a difference in the outcome of his or her own health. Therefore, it is critical for community-based programs to be delivered in a format that is understood, accessible to all, regardless of literacy, cultural beliefs and socioeconomic status (26).

Diabetes self-management requires close teamwork between patients and health care providers. It raises particular challenges for limited English proficiency Hispanics who do not have culturally and linguistically concordant health care providers. This situation is not likely to improve anytime soon, since recent national medical student 
and physician surveys show disproportionally low numbers of Hispanic health care providers compared to the increasing Hispanic population. There is a national priority for eliminating health care disparities through target and tailored translational research focused on priority populations (83). 


\section{BIBLIOGRAPHY}

1. Olokoba A, Obateru O, Olokoba L. Type 2 diabetes mellitus: A review of current trends [Internet]. Oman Medical Journal. 2012. p. 269-73. Available from: http://www.omjournal.org/articleDetails.aspx?coType=1\&aId=259

2. Ozougwu J, Obimba K, Belonwu C, Unakalamba C. The pathogenesis and pathophysiology of type 1 and type 2 diabetes mellitus. J Physiol Pathophysiol [Internet]. 2013;4:46-57. Available from: http://www.academicjournals.org/journal/JPAP/article-abstract/974E7B515872

3. CDC. Chronic Diseases: The Leading Causes of Death and Disability in the United States [Internet]. 2014 [cited 2016 Aug 1]. Available from: http://www.cdc.gov/chronicdisease/overview/

4. United States Census Bureau. Hispanic Roots-Breakdown of U.S. Hispanic population. Washington, DC; 2014.

5. Prevention C for DC and. National Diabetes Statististics Report: Estimates of Diabetes and Its Burden in the United States [Internet]. Atlanta, GA; 2014 [cited 2016 Aug 1]. Available from:

https:/www.cdc.gov/diabetes/pubs/statsreport14/national-diabetes-reportweb.pdf

6. Hu J, Amirehsani K, Wallace DC, Letvak S. Perceptions of barriers in managing diabetes: perspectives of Hispanic immigrant patients and family members. Diabetes Educ [Internet]. 2013;39:494-503. Available from: http://www.ncbi.nlm.nih.gov/pubmed/23640301

7. NHANES. National Health and Nutrition Examination Survey [Internet]. Atlanta, GA; [cited 2016 Aug 1]. Available from: https:/www.cdc.gov/Nchs/Nhanes/Nhanes2011-2012/overview_g.htm

8. de Heer HD, Salinas J, Lapeyrouse LM, Heyman J, Morera OF, Balcazar HG. Binational utilization and barriers to care among Mexican American border residents with diabetes. Rev Panam Salud Publica [Internet]. 2013;34:147-54. Available from: http://www.ncbi.nlm.nih.gov/pubmed/24233106

9. U.S. Department of Health and Human Services. DCCT and EDIC: The Diabetes Control and Complications Trial and Follow-up Study [Internet]. 2008. Available from: https://www.niddk.nih.gov/about-niddk/researchareas/diabetes/dcct-edic-diabetes-control-complications-trial-follow-upstudy/Documents/DCCT-EDIC_508.pdf 
10. Hinzmann R, Schlaeger C TTC. What Do We Need beyond Hemoglobin A1c to Get the Complete Picture of Glycemia in People with Diabetes? Int J Med Sci [Internet]. 2012;9:665-81. Available from:

http://www.medsci.org/v09p0665.htm

11. Hegar K, Heiber S, Brändle M, Christ E, Keller U. Carbohydrate Counting of Food. Swiss Med Wkly [Internet]. 2011;141. Available from:

http://www.smw.ch/content/smw-2011-13224/

12. Gökşen D, Atik Altınok Y, Ozen S, Demir G, Darcan S. Effects of carbohydrate counting method on metabolic control in children with type 1 diabetes mellitus. J Clin Res Pediatr Endocrinol [Internet]. 2014;6:74-8. Available from:

http://www.scopus.com/inward/record.url?eid=2-s2.0-

84902341269\&partnerID=tZOtx3y1

13. Haimoto H, Sasakabe T, Wakai K UH. Effects of a low-carbohydrate diet on glycemic control in outpatients with severe type 2 diabetes. Nutr Metab (Lond) [Internet]. 2009;6:52. Available from:

http://nutritionandmetabolism.biomedcentral.com/articles/10.1186/1743-70756-21

14. Son O, Efe B, Son NE, Akalin A, Kebapçi N. Investigation on carbohydrate counting method in type 1 diabetic patients. Biomed Res Int [Internet]. 2014;2014:17656. Available from:

http://www.pubmedcentral.nih.gov/articlerender.fcgi? artid=4150540\&tool=pmc entrez\&rendertype $=$ abstract

15. Rosal MC, Ockene IS, Restrepo A, White MJ, Borg A, Olendzki B, Scavron J, Candib L, Welch G, Reed G. Randomized trial of a literacy-sensitive, culturally tailored diabetes self-management intervention for low-income Latinos: Latinos en control. Diabetes Care [Internet]. 2011;34:838-44. Available from:

https:/www.ncbi.nlm.nih.gov/pmc/articles/PMC3064037/

16. Osborn CY, Amico KR, Cruz N, Ann A, Connell O, Perez-escamilla R, Kalichman SC, Scott A, Fisher JD. A Brief Culturally Tailored Intervention for Puerto Ricans with Type 2 Diabetes. Health Educ Behav [Internet]. 2011;37:849-62. Available from: http://www.ncbi.nlm.nih.gov/pmc/articles/PMC3082938/pdf/nihms271590.pdf

17. González HM, Vega WA, Rodríguez MA, Tarraf W, Sribney WM. Diabetes awareness and knowledge among Latinos: Does a usual source of healthcare matter? J Gen Intern Med [Internet]. 2009;24. Available from: http://www.ncbi.nlm.nih.gov/pmc/articles/PMC2764039/ 
18. Flesch-Kincaid Grade Level. Readability-Score [Internet]. 2011 [cited 2017 Jan 29]. Available from: https://readability-score.com

19. Association AD. Carbohydrate Counting. 2016.

20. Center JD. Diabetes and Nutrition [Internet]. 2014 [cited 2015 Dec 1]. Available from: http://www.joslin.org/info/diabetes-and-nutrition.html

21. Duggan C, Carosso E, Mariscal N, Islas I, Ibarra G, Holte S, Copeland W, Linde S, Thompson B. Diabetes prevention in Hispanics: report from a randomized controlled trial. Prev Chronic Dis [Internet]. 2014;11:E28. Available from: http://www.pubmedcentral.nih.gov/articlerender.fcgi?artid=3938962\&tool=pmc entrez\&rendertype $=$ abstract

22. Metghalchi S, Rivera M, Beeson L, Firek A, De Leon M, Cordero-MacIntyre ZR, Balcazar H. Improved clinical outcomes using a culturally sensitive diabetes education program in a Hispanic population. Diabetes Educ [Internet]. 2008;34:698-706. Available from: http://libproxy.sdsu.edu/login?url=http://search.ebscohost.com/login.aspx?direc $\mathrm{t}=$ true $\& \mathrm{db}=$ psyh $\& A N=2008-11737-007 \&$ site $=$ ehost-live\%5Cnzcorderomacintyre@1lu.edu

23. Wagner J, Bermudez-millan A, Damio G, Cd N, Segura-perez S, Chhabra J, Vergara C, Perez-escamilla R. Community health workers assisting Latinos manage stress and diabetes (CALMS-D): rationale, intervention design, implementation, and process outcomes [Internet]. Tbm. 2015. p. 415-24. Available from: https://www.ncbi.nlm.nih.gov/pmc/articles/PMC4656228/

24. Van Rompay MI, McKeown NM, Castaneda-Sceppa C, Ordovás JM, Tucker KL. Carbohydrate nutrition differs by diabetes status and is associated with dyslipidemia in Boston Puerto Rican adults without diabetes. [Internet]. The Journal of nutrition. 2013. p. 182-8. Available from: http://www.pubmedcentral.nih.gov/articlerender.fcgi?artid=3542909\&tool=pmc entrez\&rendertype $=$ abstract

25. Wheeler G, Montgomery SB, Beeson L, Bahjri K, Shulz E, Firek A, De Leon M, Cordero-MacIntyre Z. En Balance: the effects of Spanish diabetes education on physical activity changes and diabetes control. Diabetes Educ [Internet]. 2012;38:723-32. Available from: http:/tde.sagepub.com/content/38/5/723.full.pdf

26. A P-T, Gallo LC. Implementing community-based diabetes programs: the 
scripps whittier diabetes institute experience. Curr Diab Rep [Internet]. 2014;14:462. Available from: https://www.ncbi.nlm.nih.gov/pmc/articles/PMC3946451/

27. et al. Kirk JK, Arcury TA, Ip E, Bell RA. Diabetes symptoms and selfmanagement behaviors in rural older adults. Diabetes Res Clin Pract [Internet]. 2015;107(1):54-60. Available from: http://www-ncbi-nlm-nihgov.uri.idm.oclc.org/pmc/articles/PMC4309740/

28. Rolnick SJ, Pawloski PA, Hedblom BD, Asche SE, Bruzek RJ. Patient characteristics associated with medication adherence. Clin Med Res [Internet]. 2013;11:54-65. Available from:

https://www.ncbi.nlm.nih.gov/pmc/articles/PMC3692389/

29. Rosal MC, Goins K V, Carbone ET, Cortes DE. Views and preferences of lowliterate Hispanics regarding diabetes education: results of formative research. Health Educ Behav [Internet]. 2004;31:388-405. Available from: http://journals.sagepub.com/doi/pdf/10.1177/1090198104263360

30. Bishop FK, Maahs DM, Spiegel G, Owen D, Klingensmith GJ, Bortsov A, Thomas J, Mayer-Davis EJ. The carbohydrate counting in adolescents with type 1 diabetes (CCAT) study. Diabetes Spectr. 2009;22:56-62.

31. Bailey DJ DJ. MyPlate For My Family - SNAP Nutrition Education [Internet]. 1st ed. USDA; 2014. 3-23 p. Available from: https://choosemyplateprod.azureedge.net/sites/default/files/misc/MyPlateForMyFamilyEducatorsHandbook_MyPlateForMyFamily.pdf

32. Kawamura T, Takamura C, Hirose M, Hashimoto T, Higashide T. The factors affecting on estimation of carbohydrate content of meals in carbohydrate counting. 2015;24:153-65. Available from: http://www.ncbi.nlm.nih.gov/pmc/articles/PMC4628950/pdf/cpe-24-153.pdf

33. Mehta SN, Quinn N, Volkening LK, Laffel LMB. Impact of carbohydrate counting on glycemic control in children with type 1 diabetes. Diabetes Care. 2009;32:1014-6.

34. Johnson N MS. PERCEIVED BENEFITS AND BARRIERS TO THE DIABETES PREVENTION PROGRAM. Plaid J [Internet]. 2016; Available from: http://theplaidjournal.com/index.php/CoM/article/view/65/49

35. Ghafoor E, Riaz M, Eichorst B, Fawwad A, Basit A. Evaluation of diabetes conversation map??? education tools for diabetes self-management education. Diabetes Spectr. 2015;28:230-5. 
36. Khanna A, Bush AL, Swint JM, Peskin MF, Street RL, Naik AD. Hemoglobin Alc improvements and better diabetesspecific quality of life among participants completing diabetes self-management programs: A nested cohort study. Health Qual Life Outcomes [Internet]. 2012;10:1-7. Available from: http://hqlo.biomedcentral.com/articles/10.1186/1477-7525-10-48

37. CDC - Rate per 100 by Hispanic Origin - Diagnosed Diabetes - Data \& Trends Diabetes DDT [Internet]. Available from:

http://www.cdc.gov/diabetes/statistics/prev/national/figbyhispanic.htm

38. Vasquez IM, Millen B, Bissett T, Levenson SM CS. Buena Alimentacion, Buena Salud: a preventive nutrition intervention in Caribbean Latinos with type 2 diabetes. Jounal Heal Promot [Internet]. 1998; Available from: http://wwwncbi-nlm-nih-gov.uri.idm.oclc.org/pubmed/10346658

39. NIH. What is carbohydrate counting? [Internet]. December, 2013. 2013 [cited 2016 Aug 1]. Available from: https://www.niddk.nih.gov/healthinformation/health-topics/Diabetes/carbohydrate-countingdiabetes/Pages/index.aspx

40. Morales L, Lara M, Kington R, Valdez R, Escarce J. Socioeconomic, cultural, and behavioral factors affecting Hispanic health outcomes. J Health Care Poor Underserved [Internet]. 2002;13:477-503. Available from:

http://www.pubmedcentral.nih.gov/articlerender.fcgi?artid=1781361\&tool=pmc entrez\&rendertype $=$ abstract

41. Lopes Souto D, Lopes Rosado E. Use of carb counting in the dietary treatment of diabetes mellitus. Nutr Hosp [Internet]. 2010;25:18-25. Available from: http://scielo.isciii.es/pdf/nh/v25n1/revision3.pdf

42. Centers for Disease Control and Prevention. Diagnosis of Diabetes [Internet]. 2014. Available from: https://www.niddk.nih.gov/healthinformation/diabetes/diagnosis-diabetes-prediabetes

43. Fonseca VA. Defining and characterizing the progression of type 2 diabetes. Diabetes Care [Internet]. 2009;32 Suppl 2. Available from: http://www.ncbi.nlm.nih.gov/pmc/articles/PMC2811457/

44. Casey RP, Rouff MA, Jauregui-Covarrubias L. Diabetes among Latinos in the Southwestern United States: border health and binational cooperation. Rev Panam Salud Publica [Internet]. 2014;36:391-5. Available from: http://www.ncbi.nlm.nih.gov/pubmed/25711750

45. Prevention $\mathrm{C}$ for $\mathrm{DC}$ and. Rate per 100 by Hispanic origin diagnosed with 
diabetes [Internet]. 2014 [cited 2016 Aug 1]. Available from:

http://www.cdc.gov/diabetes/statistics/prev/national/figbyhispanic.htm

46. Deshpande AD, Harris-Hayes M SM. Epidemiology of Diabetes and DiabetesRelated Complications. Phys Ther [Internet]. 2008;88:1254-64. Available from: http://www.ncbi.nlm.nih.gov/pmc/articles/PMC3870323/

47. Kirk JK, Arcury TA, Ip E, Bell RA et al. Diabetes symptoms and selfmanagement behaviors in rural older adults. Diabetes Res Clin Pract [Internet]. 2015;107(1):54-60. Available from: http://www-ncbi-nlm-nihgov.uri.idm.oclc.org/pmc/articles/PMC4309740/

48. Tylee, TS TD. Glycemic Variability: Looking Beyond the A1C. Diabetes Spectr [Internet]. 2012;25:149-53. Available from:

http://spectrum.diabetesjournals.org/content/diaspect/25/3/149.full.pdf

49. American Diabetes Association. Statistics about Diabetes: Overall Numbers, Diabetes and Prediabetes [Internet]. Alexandria, VA; 2014 [cited 2016 Aug 1]. Available from: http://www.diabetes.org/diabetes-basics/statistics/

50. Nyberg ST KM. Diabetes Among Hispanics: All Are Not Equal. Alexandria, VA;

51. de Heer HD, Salinas J, Lapeyrouse LM HJ, OF M, Balcazar HG. Binational utilization and barriers to care among Mexican American border residents with diabetes. Pan Am J Public Heal [Internet]. 2013;34:147-54. Available from: http://www.ncbi.nlm.nih.gov/pubmed/24233106

52. Schneiderman N, Llabre M, Cowie CC, Barnhart J, Carnethon M, Gallo LC, Giachello AL, Heiss G, Kaplan RC, LaVange LM, et al. Prevalence of Diabetes Among Hispanics/Latinos From Diverse Backgrounds: The Hispanic Community Health Study/Study of Latinos (HCHS/SOL). Diabetes Care [Internet]. 2014;37:2233-9. Available from:

http://care.diabetesjournals.org/content/37/8/2233.full\#sec-10

53. Osborn CY, de Groot M, Wagner JA. Racial and ethnic disparities in diabetes complications in the northeastern United States: the role of socioeconomic status. J Natl Med Assoc [Internet]. 2013;105:51-8. Available from: http://www.ncbi.nlm.nih.gov.libezproxy.open.ac.uk/pmc/articles/PMC3852686/

54. Wang ML, Gellar L, Nathanson B, Pbert L, Ma Y, Ockene I RM. Decrease in Glycemic Index Associated with Improved Glycemic Control among Latinos with Type 2 Diabetes. J Acad Nutr Diet [Internet]. 2015;115:898-906. Available from: http://www-ncbi-nlm-nih- 
gov.uri.idm.oclc.org/pmc/articles/PMC4450120/

55. Boyle JP, Honeycutt AA, Narayan KMV, Hoerger TJ, Geiss LS, Chen H, Thompson TJ. Projection of diabetes burden through 2050: Impact of changing demography and disease prevalence in the U.S. Diabetes Care [Internet]. 2001;24:1936-40. Available from: http://care.diabetesjournals.org/content/diacare/24/11/1936.full.pdf

56. Association AD. A1c and eAG [Internet]. 2014 [cited 2016 Aug 1]. Available from: http://www.diabetes.org/living-with-diabetes/treatment-and-care/bloodglucose-control/a1c/

57. Spiegel G, Bortsov A, Bishop FK, Owen D, Klingensmith G, Mayer-Davis EJ MD. Randomized Nutrition Education Intervention to Improve Carbohydrate Counting in Adolescents with Type 1 Diabetes Study: Is More Intensive Education Needed? J Acad Nutr Diet [Internet]. 2012;112:1736-46. Available from: http://www-ncbi-nlm-nihgov.uri.idm.oclc.org/pmc/articles/PMC3487717/

58. Association AD. How much carbohydrate? [Internet]. 2015 [cited 2016 Aug 20]. Available from: http://www.diabetes.org/food-and-fitness/food/what-can-ieat/understanding-carbohydrates/carbohydrate-counting.html

59. Zipp C, Roehr JT, Weiss LB FF. Impact of intensive nutritional education with carbohydrate counting on diabetes control in type 2 diabetic patients. Patient Prefer Adherence [Internet]. 2010;5:7-12. Available from: http://www.pubmedcentral.nih.gov/articlerender.fcgi?artid=3034297\&tool=pmc entrez\&rendertype $=$ abstract

60. Dias VM, Pandini JA, Nunes RR, Sperandei SL, Portella ES, Cobas RA GM. Effect of the carbohydrate counting method on glycemic control in patients with type 1 diabetes. Diabetol Metab Syndr [Internet]. 2010;2. Available from: http://www-ncbi-nlm-nih-gov.uri.idm.oclc.org/pmc/articles/PMC2933609/

61. Banna JC TM. Assessing factorial and convergent validity and reliability of a food behaviour checklist for Spanish-speaking participants in US Department of Agriculture nutrition education programmes. Public Health Nutr [Internet]. 2012;14:1165-76. Available from: http://www-ncbi-nlm-nihgov.uri.idm.oclc.org/pmc/articles/PMC4677684/

62. Castro FG, Barrera M MC. The cultural adaptation of prevention interventions: resolving tensions between fidelity and fit. Prev Sci. 2004;5:41-5.

63. Broyles SL, Brennan JJ, Herzog K, Kozo J TH. Cultural Adaptation of a 
Nutrition Education Curriculum for Latino Families to Promote Acceptance. J Nutr Educ Behav [Internet]. 2011;43:S158-61. Available from: http://wwwncbi-nlm-nih-gov.uri.idm.oclc.org/pmc/articles/PMC3124678/

64. Osborn CY, Fisher JD. Diabetes education: Integrating theory, cultural considerations, and individually tailored content. Clinical Diabetes. 2008. p. $148-50$.

65. De Heer HD, Balcazar HG, Morera OF, Lapeyrouse L, Heyman J, Salinas J ZR. Barriers to Care and Comorbidities Along the U.S.-Mexico Border. Public Health Rep [Internet]. 2013;6:480-8. Available from: http://www-ncbi-nlmnih-gov.uri.idm.oclc.org/pmc/articles/PMC3804091/

66. DuBard AC GZ. Language Spoken and Differences in Health Status, Access to Care, and Receipt of Preventive Services Among U.S. Hispanics. Am J Public Health [Internet]. 2008;11:2021-8. Available from: http://www-ncbi-nlm-nihgov.uri.idm.oclc.org/pmc/articles/PMC2636430/

67. Cusi K OG. Unmet Needs in Hispanic/Latino Patients with Type 2 Duabetes Mellitus. Am J Med [Internet]. 2011;124:S2-9. Available from: http://www.amjmed.com/article/S0002-9343(11)00624-3/pdf

68. Pastors JG, Warshaw H, Daly A, Franz M KK. The Evidence for the Effectiveness of Medical Nutrition Therapy in Diabetes Management. Diabetes Care [Internet]. 2002;25:608-13. Available from: http://care.diabetesjournals.org/content/diacare/25/3/608.full.pdf

69. Otero LM, Zanetti ML. Knowledge of diabetic patients about their disease before and after 1 implementing a diabetes education program. Nurs Res. 2008;16:231-7.

70. Chang J, Guy MC, Rosales C, de Zapien JG, Staten LK, Fernandez ML, Carvajal SC. Investigating social ecological contributors to diabetes within Hispanics in an underserved U.S.-Mexico border community. Int J Environ Res Public Health [Internet]. 2013;10:3217-32. Available from: http://www.mdpi.com/1660-4601/10/8/3217

71. Corriere MD, Minang LB, Sisson SD, Brancati FL, Kalyani RR. The use of clinical guidelines highlights ongoing educational gaps in physicians' knowledge and decision making related to diabetes. BMC Med Educ [Internet]. 2014;14:186. Available from:

http://www.pubmedcentral.nih.gov/articlerender.fcgi?artid=4162949\&tool=pmc entrez\&rendertype $=$ abstract 
72. Blanks SH, Treadwell H, Bazzell A, Graves W, Osaji O, Dean J, McLawhorn JT SJ. Community Engaged Lifestyle Modification Research: Engaging Diabetic and Prediabetic African American Women in Community-Based Interventions. J Obes [Internet]. 2016; Available from: https://www-ncbi-nlmnih-gov.uri.idm.oclc.org/pmc/articles/PMC4963564/

73. Centers for Disease Control and Prevention. The Power of Prevention: Chronic disease...The public health challenge of the 21st century. [Internet]. 2009. Available from: http://www.cdc.gov.uri.idm.oclc.org/chronicdisease/pdf/2009Power-of-Prevention.pdf

74. Pérez-Escamilla R, Damio G, Chhabra J, Fernandez ML, Segura-Pérez S, VegaLópez S, Kollannor-Samuel G, Calle M, Shebl FM, D’Agostino D. Impact of a community health workers-led structured program on blood glucose control among Latinos with type 2 diabetes: The DIALBEST Trial. Diabetes Care [Internet]. 2015;38:197-205. Available from: http://care.diabetesjournals.org/content/38/2/197

75. Fred M, Hongjian Y, Biehl M, Aydin M, Levy M PN. Reach of Supplemental Nutrition Assistance Program-Education (SNAP-Ed) Interventions and Nutrition and Physical Activity-Related Outcomes, California, 2011-2012. Prev Chronic Dis [Internet]. 2012;12. Available from: http://www.ncbi.nlm.nih.gov/pmc/articles/PMC4362390/

76. Hersey JC, Cates SC, Blitstein JL WP. SNAP-Ed Can Improve Nutrition of Low-Income Americans Across Lifespan. 2014.

77. Kris-Etherton PM, Akabas SR, Bales CW, Bistrian B, Braun L, Edwards MS, Laur C, Lenders CM, Levy MD, Palmer CA, et al. The need to advance nutrition education in the training of health care professionals and recommended research to evaluate implementation and effectiveness. Am J Clin Nutr. 2014;99.

78. Knowler WC, Barrett-Connor E, Fowler SE, Hamman RF, Lachin JM, Walker EA, Nathan DM, Diabetes Prevention Program Research Group. Reduction in the incidence of type 2 diabetes with lifestyle intervention or metformin. N Engl J Med [Internet]. 2002;346:393-403. Available from:

http://www.nejm.org/doi/pdf/10.1056/NEJMoa012512\%5Cnhttp://www.ncbi.nl m.nih.gov/pubmed/11832527\%5Cnhttp://www.pubmedcentral.nih.gov/articlere nder.fcgi?artid=PMC1370926

79. Fonseca V, Kirkman S, Darsow T, Ratner RE. The American Diabetes Association Diabetes Research Perspective [Internet]. Diabetes care. 2012. p. 
1380-7. Available from:

https://dialnet.unirioja.es/servlet/articulo?codigo $=4069025 \&$ info=resumen\&idio $\mathrm{ma}=\mathrm{ENG}$

80. NIH. The A1c Test and Diabetes. 2014.

81. Tripp-Reimer T, Choi E, Kelley LS EJ. Cultural Barriers to Care: Inverting the Problem. Diabetes Spectr [Internet]. 2001;14:13-22. Available from:

http://spectrum.diabetesjournals.org/content/14/1/13.full.pdf $+\mathrm{html}$

82. Laurenzi A, Bolla AM, Panigoni, G, Doria V, Uccellatore AC, Peretti E, Saibene A, Galimberti G, Bosi E SM. Effects of Carbohydrate Counting on Glucose Control and Quality of Life Over 24 Weeks in Adult Patients With Type 1 Diabetes on Continuous Subcutaneous Insulin Infusion. Diabetes Care [Internet]. 2012;34:823-7. Available from:

https://www.ncbi.nlm.nih.gov/pmc/articles/PMC3064035/

83. L L, Grant RW. Closing the gap: eliminating health care disparities among Latinos with diabetes using health information technology tools and patient navigators. J Diabetes Sci Technol [Internet]. 2012;6:169-76. Available from: https://www.ncbi.nlm.nih.gov/pmc/articles/PMC3320835/ 
APPENDIX B - SIGN-UP FORM (DEMOGRAPHICS, RECRUITMENT,

ASSESSEMENT)

THE

UNIVERSITY

OF RHODE ISLAND

COLLEGE OF

THE ENVIRONMENT

AND LIFE SCIENCES

The University of Rhode Island

Department of Nutrition and Food Sciences

Departamento de Nutrición y Ciencias de los Alimentos

125 Fogarty Hall Kingston, RI 02881

Nutrition Study/Estudio de la Nutrición

Recruitment Form / Formulario de Contratación

\section{PLEASE PRINT / POR FAVOR IMPRIMIR}

Date / Fecha:

Name / Nombre:

Home Phone number / Número de teléfono de casa:

Cell phone number / teléfono celular:

Email / Correo electrónico:

Gender / Género: $\square$ Male / Masculino $\square$ Female / Femenino Age / Años:

Which language do you prefer? / ¿En qué idioma prefiere?

$\square$ English / Inglés $\quad \square$ Spanish / Español

Choose all that apply: / Elija todo lo que corresponda:

$\square$ Hispanic / Hispano $\square$ White / Blanco

$\square$ Black or African American / Negro o Africano Americano $\quad \square$ Other / Otro

Country of origin / País de origen: 
How long have you lived in the U.S.? / ¿Cuánto tiempo ha vivido en los Estados Unidos?

How long have you had diabetes? / ¿Cuánto tiempo ha tenido diabetes?

Emergency contact person and phone number / Persona de contacto y número de teléfono de emergencia:

Check the best answer ( $\square)$ : / Marque la mejor respuesta ( $\square)$ :

1. Have you had diabetes education before? / ¿Ha tenido educación sobre diabetes antes?

$\square$ Yes / Sí $\square$ No / No $\square$ I don’t know / No lo sé

2. Do you follow a diabetic meal plan? / ¿Usted sigue un plan de alimentación para diabéticos?

Yes / Sí $\quad \square$ No / No $\quad \square$ I don’t know / No lo sé

3. Do you know what carbohydrates are? / ¿Sabe qué son los carbohidratos?

$\square$ Yes / Sí $\quad \square$ No / No $\quad \square$ I don’t know / No lo sé

4. Do you know what carbohydrate counting is? / ¿Sabe qué es el conteo de carbohidratos?

Yes / Sí $\quad \square$ No / No $\quad \square$ I don’t know / No lo sé

5. Do you control your portion sizes? / ¿Usted controla el tamaño de sus porciones?

$\square$ Yes / Sí $\square$ No / No $\square$ I don’t know / No lo sé

6. Do you read the Nutritional Facts Labels? / ¿Lee las etiquetas de los alimentos?

$\square$ Yes / Sí $\square$ No / No $\square$ I don’t know / No lo sé

7. What has been most difficult to control your diabetes? / ¿Qué ha sido lo más difícil de controlar su diabetes? $\square$ Blood sugar / Azúcar en la sangre $\square$ Diet / Dieta Other / Otro describe / describir:

Thank you for your cooperation! / ; Gracias por su cooperación! 


\title{
APPENDIX C - CONSENT FORM
}

\section{THE}

\author{
UNIVERSITY \\ OF RHODE ISLAND \\ COLLEGE OF \\ HEALTH SCIENCES \\ DEPARTMENT OF NUTRITION AND FOOD SCIENCES \\ 125 Fogarty Hall, Kingston, RI 02881 USA $\quad$ p: $401.874 .2253 \quad$ f: 401.874 .5974 web.uri.edu/nfs \\ Nutrition Study
}

\section{CONSENT FORM FOR RESEARCH}

You have been invited to take part in a research project described below being conducted under the direction of Dr. Geoffrey Greene from the Department of Nutrition and Food Sciences of the University of Rhode Island. The researcher will explain the project to you in detail. You should feel free to ask questions. If you have more questions later, contact Flavia Cattaneo, the person primarily responsible for this study at 401-368-8807. You must be at least 18 years old to be in this research project.

Inclusion criteria: must be self-identified Hispanic, between 25-70 years old, diagnosed with diabetes.

Exclusion criteria: life-threatening condition and inability to attend to all 3 sessions.

Purpose of the project: the purpose of this study is to determine if Hispanics living with type 2 diabetes will increase knowledge and skills about carbohydrate counting through a nutrition education intervention.

If you decide to take part in this study here is what will happen: you will attend 3-one hour workshops on carbohydrate counting held once per week at the same time at the Rhode Island Free Clinic. You will be involved in hands-on activities during the workshops such as learning how to read food labels, measure portions sizes and counting carbohydrate in foods. You will take a knowledge survey on the first and third workshop. In the third workshop you will also complete a carbohydrate counting activity and a short evaluation of the workshops.

Risks or discomfort: there are minimal risks because the study is just providing you with information about healthy eating with diabetes. However, we recommend you follow the blood glucose monitoring recommendations provided by the Free Clinic and follow up with the Free Clinic if you blood glucose is too low or too high. Checking your blood glucose levels and counting carbohydrates are important in helping you manage your diabetes. 
Benefit of this study: participating in this study will help you learn more about carbohydrates and how to control your diabetes. Your participation will also help us learn the best ways of teaching people like you with Type 2 diabetes how to control their blood sugar and improve their health.

Confidentiality: your part in this study is confidential. Although you will have your name on some forms, your name will never be recorded for data analysis and all reports based on the study will be confidential. The forms with your name will be maintained at the URI-Providence Campus at a locked cabinet file. The researchers and the University of Rhode Island will protect your privacy.

Decision to quit at any time: the decision to take part in this study is up to you. You do not have to participate. Whatever you decide will in no way affect your participation in the Rhode Island Free Clinic. If you wish to quit, simply inform Flavia Cattaneo (401-368-8807) of your decision.

Rights and Complaints: if you are not satisfied with the way this study is performed, you may discuss your complaints with Flavia Cattaneo 401-368-8807 or with Geoffrey Greene at 401-874-4028, anonymously if you choose. In addition, if you have questions about your rights as a research participant, you may contact the office of the Vice President for Research and Economic Development, 70 Lower College Road, Suite 2, University of Rhode Island, Kingston, Rhode Island, telephone: (401) 8744328 .

You have read the Consent Form. Your questions have been answered. Your signature on this form means that you understand the information and you agree to participate in this study.

Signature of Participant

Typed/printed Name
Signature of Researcher

Typed/printed name

Date

Date

Please sign both consent forms, keeping one for yourself. 


\section{Estudio de la Nutrición}

\section{CONSENTIMIENTO PARA LA INVESTIGACIÓN}

Se le ha invitado a participar en un proyecto de investigación que se describe a continuación y se está llevando a cabo bajo la dirección del Dr. Geoffrey Greene, del Departamento de Nutrición y Ciencias de los Alimentos de la Universidad de Rhode Island. El investigador va a explicar el proyecto en detalle. Usted debe sentirse libre de hacer preguntas. Si usted tiene más preguntas después, póngase en contacto con Flavia Cattaneo, la principal responsable de este estudio, al 401-368-8807. Debe tener al menos 18 años de edad para estar en este proyecto de investigación.

Criterios de inclusión: debe ser auto-identificado Hispano, entre 25-70 años de edad, con diagnóstico de diabetes.

Criterios de exclusión: condiciones que amenazan la vida y la imposibilidad de asistir a todas las sesiones de 3 .

Objetivo del proyecto: el propósito de este estudio es determinar si los hispanos que viven con diabetes tipo 2 incrementarán su conocimiento y habilidades sobre el conteo de carbohidratos a través de una intervención de educación nutricional.

Si decide participar en este estudio, estó es lo que sucederá: Asistirá a 3 talleres de una hora sobre el conteo de carbohidratos una vez por semana a la misma hora en el Rhode Island Free Clinic. Usted estará involucrado en actividades prácticas durante los talleres tales como aprender a leer las etiquetas de los alimentos, medir tamaños de las porciones y el conteo de carbohidratos en los alimentos. Tendrá que completar una encuesta de conocimientos en el primer y tercer taller. En el tercer taller también completará una actividad de conteo de carbohidratos y una breve evaluación de los talleres.

Riesgos o molestias: existen riesgos mínimos ya que el estudio sólo le está proporcionando información sobre la alimentación saludable con diabetes. Sin embargo, le recomendamos que siga las recomendaciones de monitorización de glucosa en sangre proporcionados por la clínica libre y el seguimiento con la clínica libre si la glucosa en sangre es demasiado bajo o demasiado alto. Comprobación de los niveles de glucosa en sangre y contar los carbohidratos son importantes para ayudar a controlar la diabetes.

Beneficio de este estudio: la participación en este estudio ayudará a aprender más acerca de los carbohidratos y cómo controlar su diabetes. Su participación también nos ayudará a aprender las mejores maneras de enseñar a la gente con diabetes tipo 2 como usted a controlar su azúcar en la sangre y mejorar su salud.

Confidencialidad: su participación en este estudio es confidencial. A pesar de que tendrá su nombre en algunas formas, su nombre nunca será grabado para el análisis de 
datos y todos los informes basados en el estudio serán confidencial. Las formas con su nombre se mantendrán en el campus de URI-Providence en un archivo dentro de un armario cerrado con llave. Los investigadores y la Universidad de Rhode Island protegerán su privacidad.

Decisión de renunciar en cualquier momento: la decisión de participar en este estudio depende de usted. Usted no tiene que participar. Lo que decide de ninguna manera afectará su participación en el Rhode Island Free Clinic. si desea renunciar, simplemente informe a Flavia Cattaneo (401-368-8807) de su decisión.

Derechos y Quejas: si no está satisfecho con la forma en que se lleva a cabo este estudio, es posible hablar de sus quejas con Flavia Cattaneo 401-368-8807 o con Geoffrey Greene en el 401-874-4028, de forma anónima si lo desea. Además, si tiene alguna pregunta sobre sus derechos como participante en la investigación, puede comunicarse con la oficina del vicepresidente de Investigación y Desarrollo Económico, 70 Bajo College Road, Suite 2, Universidad de Rhode Island, Kingston, Rhode Island, teléfono: (401) 874-4328.

Ha leído el formulario de consentimiento. Sus preguntas han sido contestadas. Su firma en este formulario significa que usted entiende la información y acepta participar en este estudio.

Firma del Participante

$\overline{\text { Nombre escrito/en letra de molde }}$

Fecha
Firma del Investigador

$\overline{\text { Nombre escrito/en letra de molde }}$

Por favor firme los dos formularios de consentimiento, manteniendo una para usted.

Fecha 
THE

\section{UNIVERSITY \\ OF RHODE ISLAND}

\section{COLLEGE OF}

THE ENVIRONMENT

AND LIFE SCIENCES
For researcher use only: Pre Survey

Post Survey

Date

ID\#

The University of Rhode Island

Department of Nutrition and Food Sciences

125 Fogarty Hall Kingston, RI 02881

Nutrition Study

\section{Knowledge Assessment}

Please check $\square$ the best answer:

1. How many food groups are included in the USDA MyPlate?
$\square 6$
$\square 3$
$\square 5$
$\square 2$
$\square 4$

2. Which food groups from the USDA MyPlate contain carbohydrates?

$\square$ grains

$\square$ grains and vegetables

$\square$ fruits

$\square$ grains, starchy vegetables, fruits and dairy

$\square$ grains, vegetables and protein

3. How many grams of carbohydrates are equal to 1 serving of carbohydrate?
$\square 10 \mathrm{~g}$
$\square 15 \mathrm{~g}$
$\square 5 \mathrm{~g}$
$\square 20 \mathrm{~g}$
$\square 25 \mathrm{~g}$

4. How many grams of carbohydrates do you need per snack?
$\square 10 \mathrm{~g}$
$\square 30 \mathrm{~g}$
$\square 45 \mathrm{~g}$
$\square 15-20 \mathrm{~g}$
$\square 15 \mathrm{~g}$ 
5. How many grams of carbohydrates do you need per meal? (breakfast, lunch, dinner)

$\square 30 \mathrm{~g}$

$\square 45-60 \mathrm{~g}$

$\square 60 \mathrm{~g}$

$\square 15 \mathrm{~g}$

$\square 100 \mathrm{~g}$

6. If the serving size on the Nutrition Facts Label is 1 cup and you eat 2 cups, how many total servings did you eat?

$\square 1$ serving

$\square 4$ servings

$\square 3$ servings

$\square 2$ servings

$\square 5$ servings

7. How many servings of carbohydrates are in 45-60 g?

$\square 2$ servings

$\square 10$ servings

$\square 20$ servings

$\square 5$ servings

$\square$ 3-4 servings

8. According to USDA MyPlate half (1/2) of your plate should be?

$\square$ grains

$\square$ fruits and vegetables

$\square$ vegetables and protein

$\square$ grains and vegetables

$\square$ vegetables

9. Where can you find carbohydrates?

$\square$ regular soda

$\square$ water

$\square$ corn

$\square$ regular soda and corn

$\square$ regular soda, corn and tortilla

10. If you eat $30 \mathrm{~g}$ of yucca, how many serving(s) of carbohydrate(s) do you eat?

$(1$ serving $=15 \mathrm{~g})$

$\square 30$ servings

$\square 10$ servings

$\square 1$ serving

$\square 2$ servings

$\square 15$ servings 
The University of Rhode Island

Departamento de Ciencias de la Nutrición y Alimentación

125 Fogarty Salón Kingston, RI 02881

Estudio de la Nutrición

\section{Evaluación de conocimientos}

For researcher use only:

Pre Survey

Post Survey

Date

ID\#

Por favor, marque $\square$ la mejor respuesta:

1. ¿Cuántos grupos de alimentos se incluyen en MiPlato del USDA?

$\square 6$

$\square 3$

$\square 5$

$\square 2$

$\square 4$

2. ¿Qué grupos de alimentos en MiPlato del USDA contienen carbohidratos?

$\square$ granos

$\square$ granos y vegetales

$\square$ frutas

$\square$ granos, vegetales de almidón, frutas y productos lácteos

$\square$ granos, vegetales y proteínas

3. ¿Cuántos gramos de carbohidratos son iguales a 1 porción de carbohidratos?

$\square 10 \mathrm{~g}$

$\square 15 \mathrm{~g}$

$\square 5 \mathrm{~g}$

$\square 20 \mathrm{~g}$

$\square 25 \mathrm{~g}$

4. ¿Cuántos gramos de carbohidratos necesita en cada merienda?
$\square 10 \mathrm{~g}$
$\square 30 \mathrm{~g}$
$\square 45 \mathrm{~g}$
$\square 15-20 \mathrm{~g}$
$\square 15 \mathrm{~g}$

5. ¿Cuántos gramos de carbohidratos necesita en cada comida? (desayuno, almuerzo, cena)
$\square 30 \mathrm{~g}$
$\square$ 45-60 g
$\square 60 \mathrm{~g}$
$\square 15 \mathrm{~g}$
$\square 100 \mathrm{~g}$ 
6. Si el tamaño de la porción en la etiqueta de información nutricional es 1 taza y se come 2 tazas, ¿Cuántas porciones en total se comió?

$\square 1$ porción

$\square 4$ porciones

$\square 3$ porciones

$\square 2$ porciones

$\square 5$ porciones

7. ¿Cuántas porciones de carbohidratos hay en 45-60 g?

$\square 2$ porciones

$\square 10$ porciones

$\square 20$ porciones

$\square$ 5-10 porciones

$\square$ 3-4 porciones

8. ¿De acuerdo con el USDA MyPlate la mitad (1/2) de su plato debe ser?

$\square$ granos

$\square$ frutas y vegetales

$\square$ vegetales y proteínas

$\square$ granos y vegetales

$\square$ vegetales

9. ¿Dónde se pueden encontrar los carbohidratos?

$\square$ soda regular

$\square$ agua

$\square$ maíz

$\square$ soda regular y maíz

$\square$ soda regular, maíz y tortilla

10. Si usted come 30 gramos de yuca, cual es la cantidad de porción(es) de carbohidrato(s) que se comió? (1 porción = $15 \mathrm{~g})$
$\square 30$ porciones
$\square 10$ porciones
$\square 1$ porción
$\square 2$ porciones
$\square 15$ porciones 
THE

UNIVERSITY

OF RHODE ISLAND

COLLEGE OF

THE ENVIRONMENT

AND LIFE SCIENCES

For researcher use only:

Date

ID\#

The University of Rhode Island

Department of Nutrition and Food Sciences

125 Fogarty Hall Kingston, RI 02881

Nutrition Study

\section{Skill of Carbohydrate Counting Assessment}

Follow directions below:

1. Take all food pictures out of the plastic bag

2. Build a meal containing between $45-60 \mathrm{~g}$ of carbohydrate by attaching pictures on the proper food groups of the ChooseMyPlate

3. Count the total amount of carbohydrate and write it below:

The total carbohydrate is

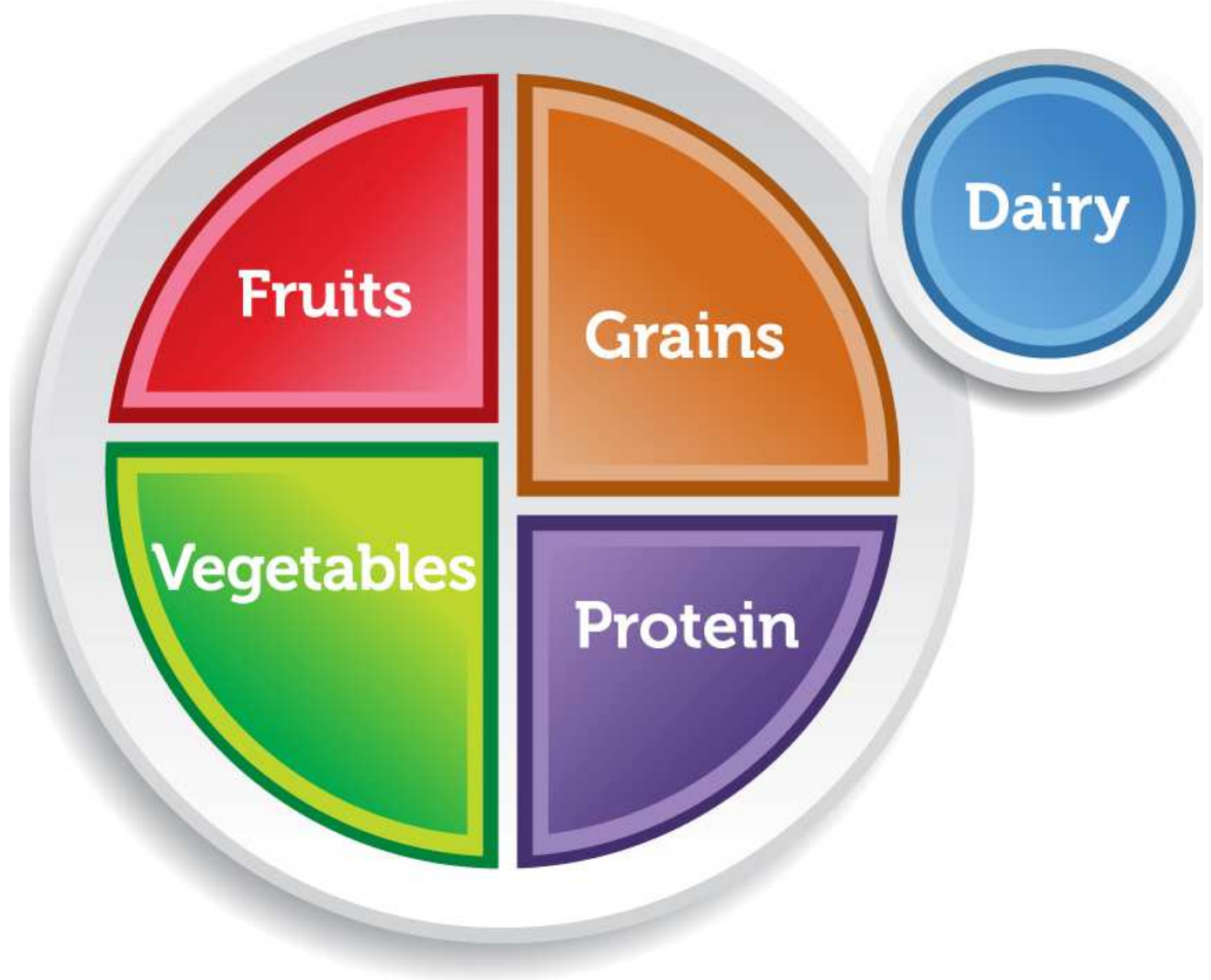


La Universidad de Rhode Island

Departamento de Ciencias de la Nutrición y Alimentación

125 Fogarty Salón Kingston, RI 02881

Estudio de la Nutrición

La Habilidad de Conteo de Carbohidratos

Siga las instrucciones a continuación:

Sólo para uso investigador:

Date

ID\#

1. Tome todas las imágenes de alimentos de la bolsa de plástico

2. Construir una comida que contiene entre $45-60 \mathrm{~g}$ de carbohidratos mediante la fijación de imágenes en el ChooseMyPlate

3. Contar la cantidad total de hidratos de carbono y escribir a continuación:

\section{El total de carbohidratos es}

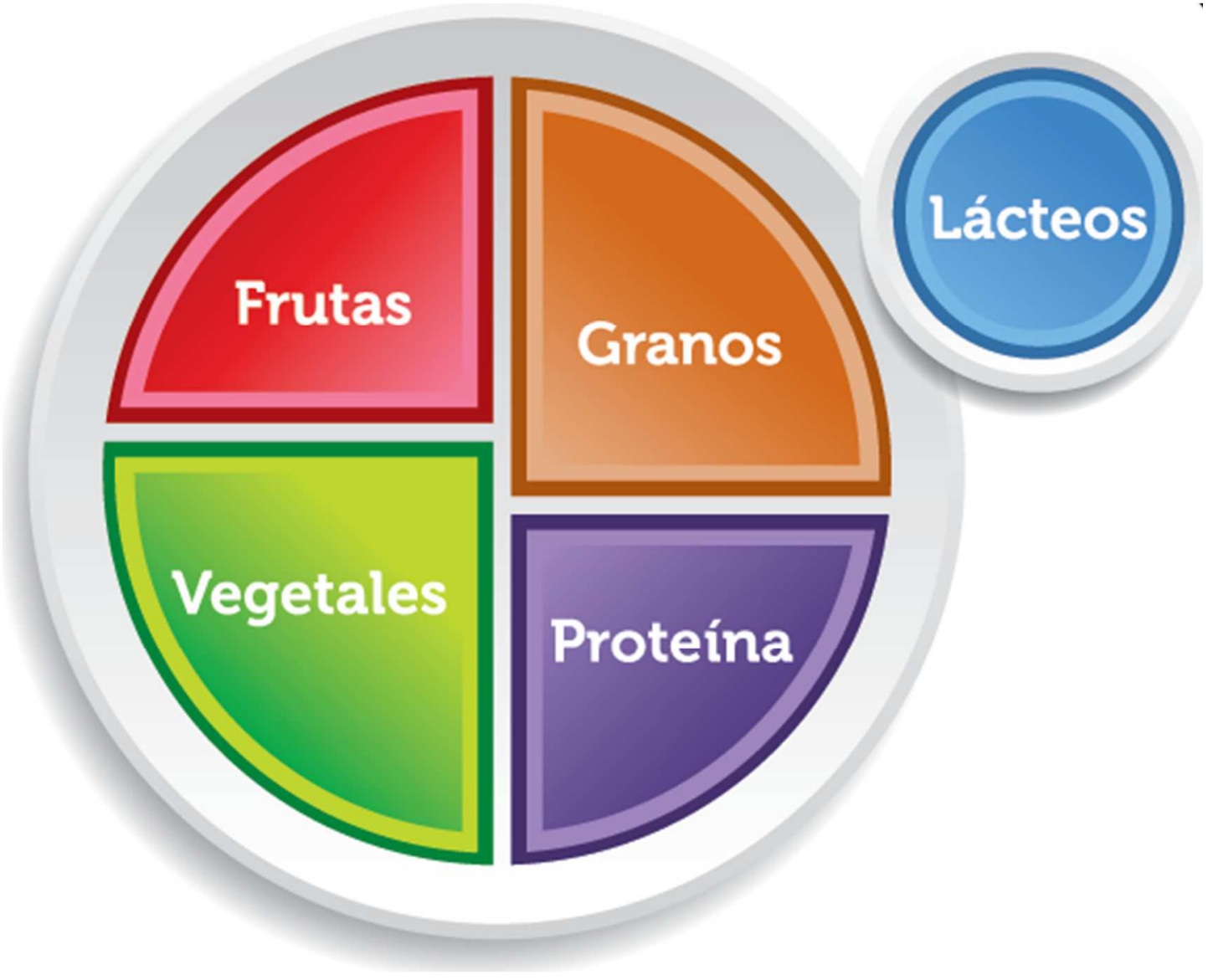


APPENDIX F - PROGRAM EVALUATION

THE

\section{UNIVERSITY}

OF RHODE ISLAND

\section{COLLEGE OF}

THE ENVIRONMENT

AND LIFE SCIENCES

The University of Rhode Island

Department of Nutrition and Food Sciences

125 Fogarty Hall Kingston, RI 02881

Nutrition Study

Please indicate your level of satisfaction with each of the following (check one 0 ):

\begin{tabular}{|c|c|c|c|c|c|}
\hline 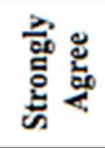 & 100 & 0 & 10 & $\begin{array}{lll}0 & 0\end{array}$ & 0 \\
\hline 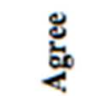 & 00 & 0 & 0 & $\begin{array}{lll}0 & 0\end{array}$ & 0 \\
\hline 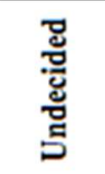 & 00 & 0 & 10 & $\begin{array}{lll}0 & 0\end{array}$ & 0 \\
\hline 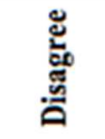 & 00 & 0 & 10 & $\begin{array}{lll}0 & 0\end{array}$ & 0 \\
\hline 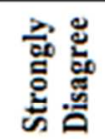 & 00 & 0 & 10 & $\begin{array}{lll}0 & 0\end{array}$ & 0 \\
\hline & 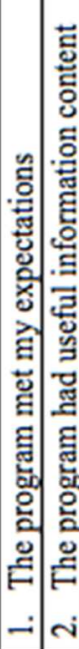 & 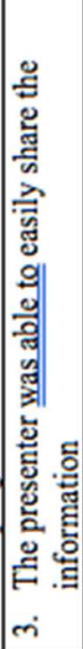 & 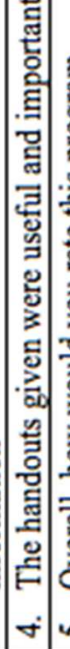 & 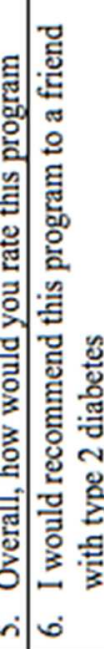 & 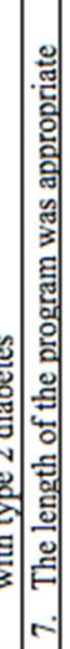 \\
\hline
\end{tabular}


Por favor, indique su nivel de satisfacción con cada uno de los siguientes (marque un 0 ):

\begin{tabular}{|c|c|c|c|c|c|c|c|}
\hline 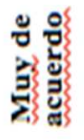 & 0 & 0 & 0 & 0 & 0 & 0 & 0 \\
\hline 范 & 0 & 0 & 0 & 0 & 0 & 0 & 0 \\
\hline 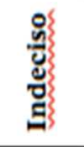 & 0 & 0 & 0 & 0 & 0 & 0 & 0 \\
\hline 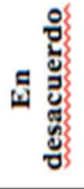 & 0 & 0 & 0 & 0 & 0 & 0 & 0 \\
\hline 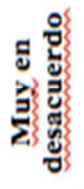 & 0 & 0 & 0 & 0 & 0 & 0 & 0 \\
\hline & 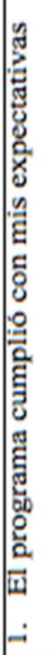 & 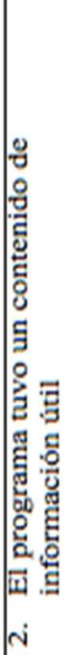 & 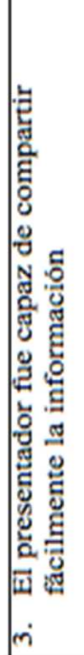 & 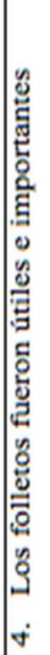 & 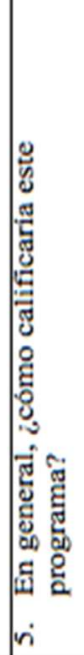 & 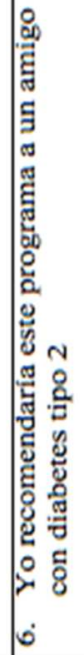 & 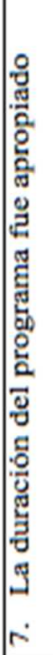 \\
\hline
\end{tabular}




\section{Make MyPlate Your Plate}

- MyPlate reminds you to include foods from all 5 food groups at dinner.

- Use a smaller plate, bow or glass to eat a healthy amount of food.

- Limit foods high in fat, added sugars and salt.

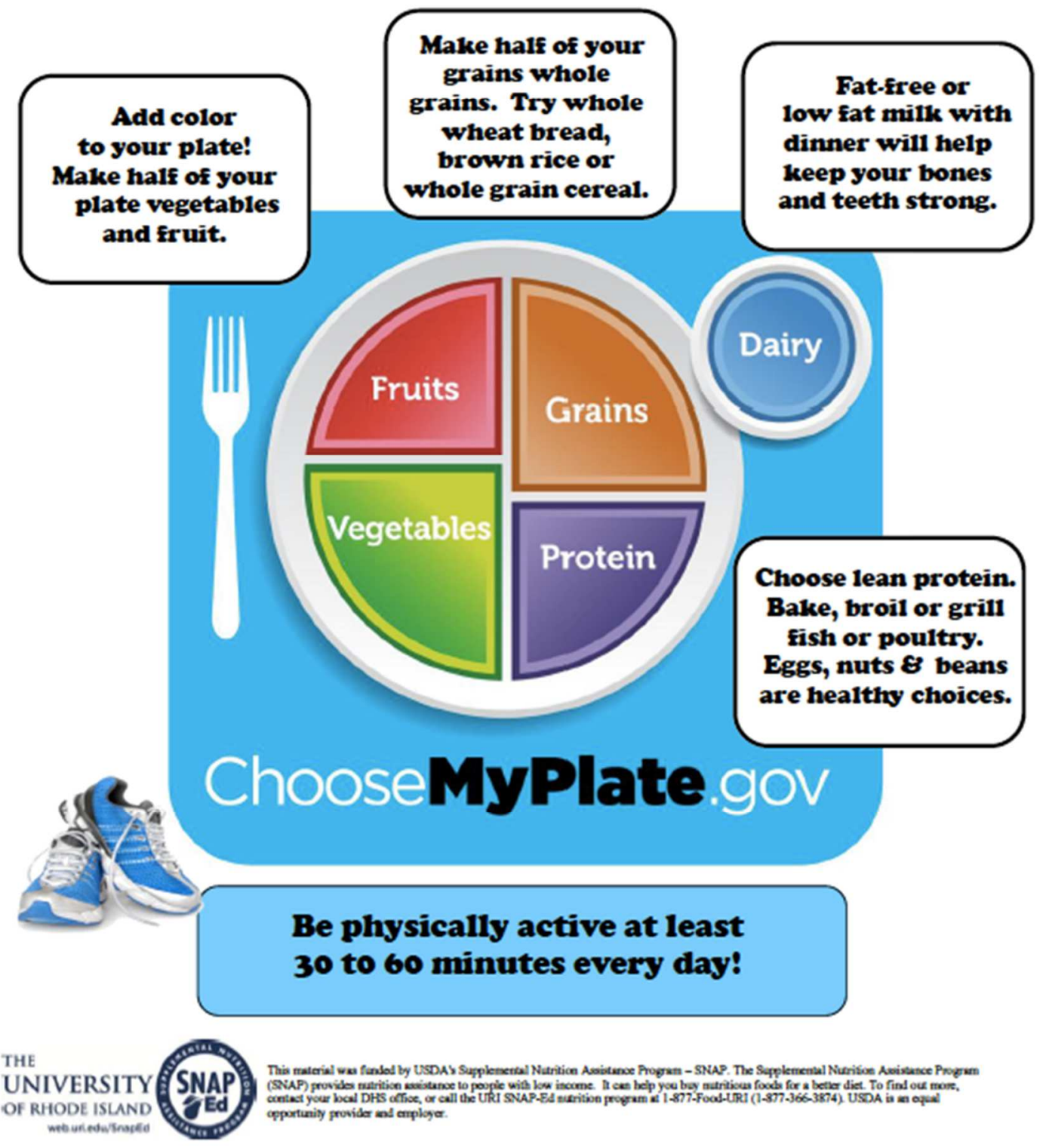




\section{Haga Miplato Su Plato}

- MiPlato le recuerda a incluir alimentos de los 5 grupos en la cena.

- Use un plato, cuenco o vaso más pequeño para comer una porción saludable de comida.

- Limite los alimentos con muchas grasas, axúcares agregadas y sal.

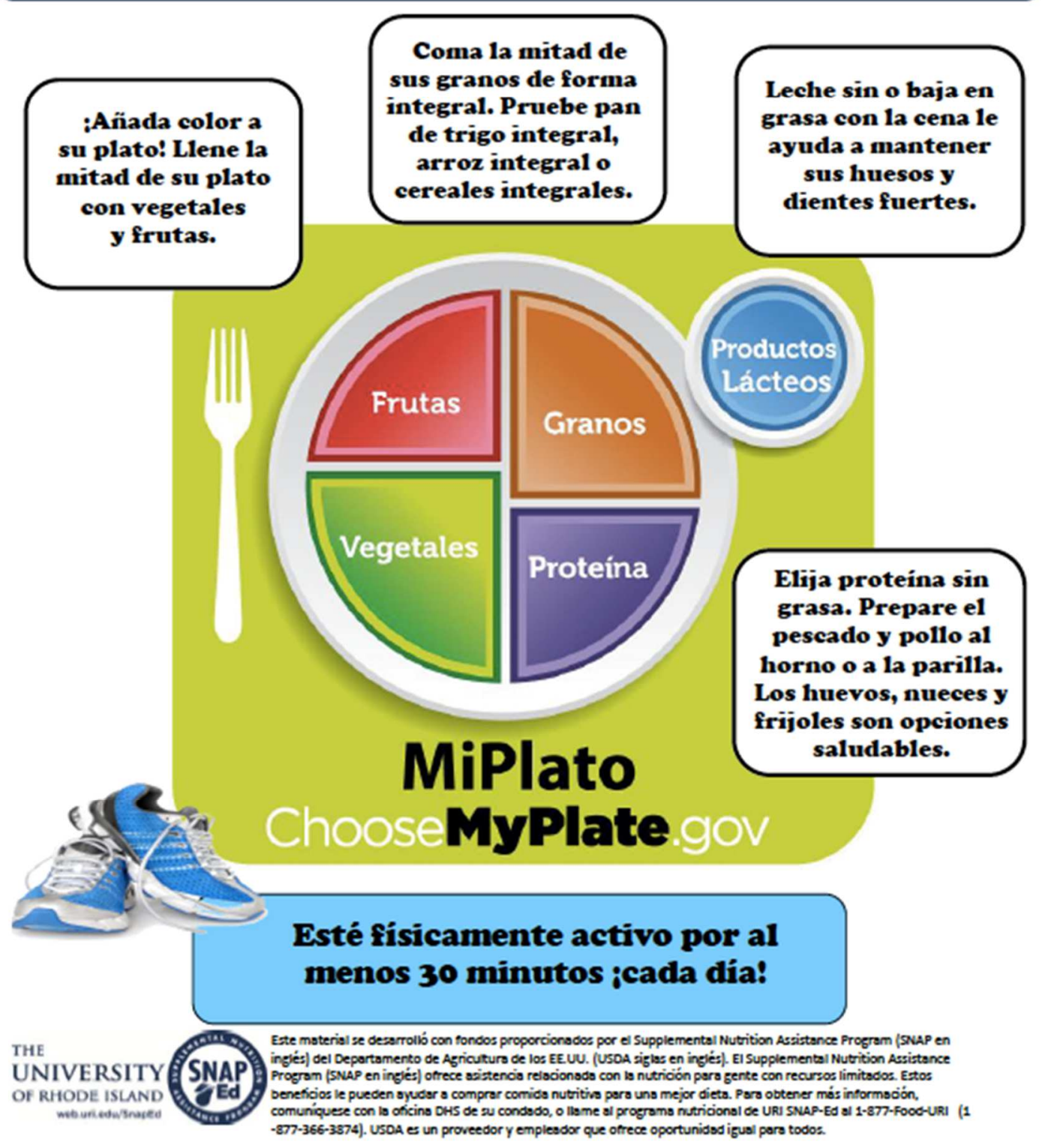



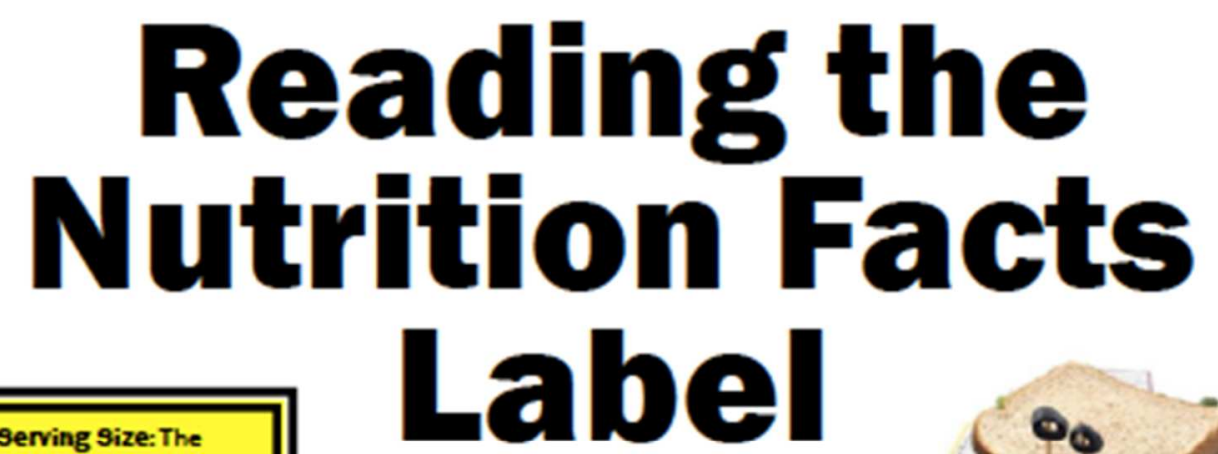

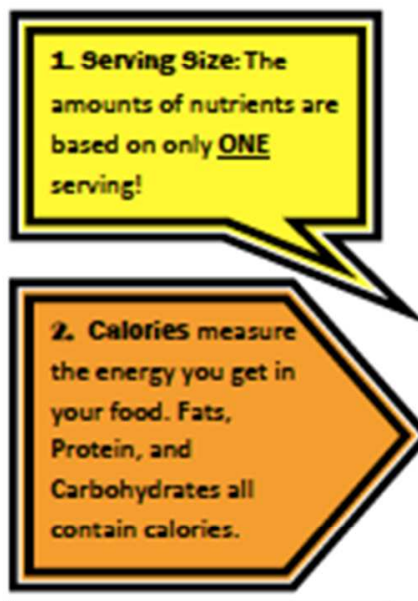

3. Nutrients:

RED:- Limit these nutrients. Trans fat does not have a $\%$ daily value because it should be consumed very rarely. GREEN: these healthy nutrients.

WHITE: Carbohydrates provide us with most of our energy. Sugars can be naturally occurring or added to foods. Added sugars should be limited. Protein does not have a $\%$ daily value because everyone needs different amounts.

\section{Nutrition Facts}

Serving Size 1 cup (332 g) Servings Per Container 10 pmourt persering

\begin{tabular}{|l|r|}
\hline Colories 170 & \multicolumn{2}{|c|}{ Colories from Fat is } \\
\hline & SDaic Value' \\
\hline Total Fat 25 & $3 \%$ \\
\hline
\end{tabular}

\begin{tabular}{|c|l|}
\hline Total Fat 25 & $3 \%$ \\
Soturated Fat o5 & $0 \%$ \\
\hline
\end{tabular}
Trans Fat og

\begin{tabular}{|l|r|}
\hline Oroleterol 15mg & $5 \%$ \\
\hline Sodium & Tsomg \\
\hline
\end{tabular}

\begin{tabular}{|l|r|}
\hline Sodium 380ms & $2 \%$ \\
\hline
\end{tabular}

Sodium 380ms

\begin{tabular}{|l|l|}
\hline Total Carbohydrate 29g & $10 \%$ \\
\hline Dietsy fider $5 g$ & $20 \%$ \\
\hline
\end{tabular}

Sugars 8 g

Protein 9

Vitamin A

\begin{tabular}{|l|r|}
\hline Vitamin A & $20 \%$ \\
\hline Vitarrin C & $40 \%$ \\
\hline Colcium & $4 \%$ \\
\hline Iron & $5 \%$ \\
\hline Fon
\end{tabular}

Iron

"Percent Daly Valies are besied on a 2000 calorie det. Your Dally Volves may be higher or lower dependins on your calorien needs.

\begin{tabular}{l} 
rour caicrie neecs. \\
\hline
\end{tabular}

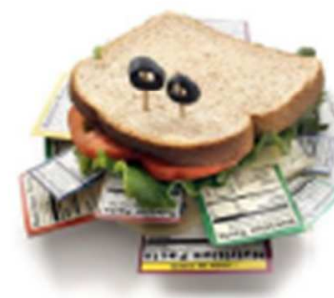

4. \% Daily Value: are based on a 2,000 calorie diet. This may be higher or lower depending on your age, if you are male or female, and your activity level.

$5 \%$ or less is Low $20 \%$ or more is High

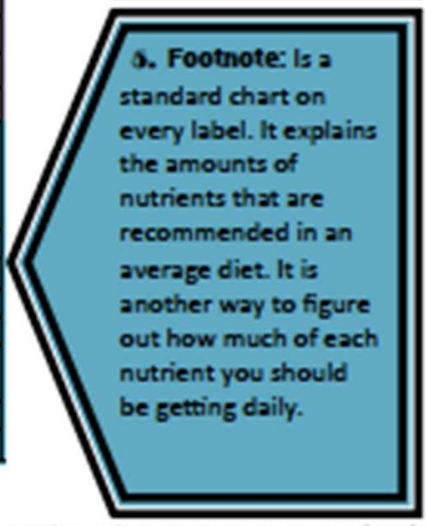

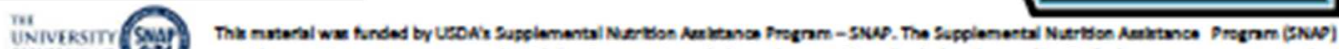

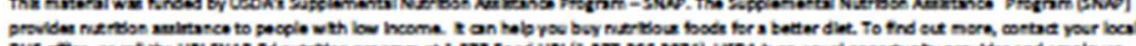

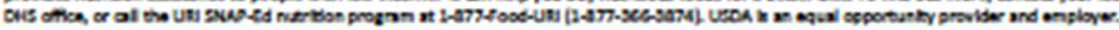




\section{Como Leer la Etiqueta de Datos Nutricionales}

1. Tamaño por ración: Las cantidades de los nutrientes están basadas en rólo iUNA porción!

2. Las Calorías miden la energía que obtiene de la comida. Proteina, Grasas y Carbohidratoa contienen calorias.

3. Nutrientes:

ROLO: Limite estos nutrientes. La grasa trans no tiene un $\%$ valor diario porque lo debe consumir muy raramente.

VERDE: Consuma bastante de estor nutriente: saludables.

BLANCO: Los carbohidratos nos dan la mayoria de nuestra energia. Los azucares pueden ocurrir naturalmente o ser agregados a la comida. Debe limitar los azucares agregados. La proteína no tiene un $\%$ valor diario porque cada persona necesita una cantidad diferente.

\section{Datos Nutricionales}

Tamaño por Ración 1 taza (332 g)

Porcionez en el Paquete 10

Cavidad per tadén

\begin{tabular}{|l|l|}
\hline Calorias 170 & Colorías de is Grasa 15 \\
\hline
\end{tabular}

\begin{tabular}{|l|c|}
\hline & Calorias de is Grasa 18 \\
\hline & SEValor Diario" \\
\hline
\end{tabular}

\begin{tabular}{|c|c|c|c|}
\hline \multicolumn{3}{|c|}{$\begin{array}{l}\text { Grasa Total 25 } \\
\text { Grasa Sturado of } \\
\text { Grasa Trans of }\end{array}$} & $\begin{array}{l}3 \% \\
0 \%\end{array}$ \\
\hline \multicolumn{3}{|c|}{ Colesterol $15 \mathrm{mb}_{5}$} & $5 \%$ \\
\hline \multicolumn{3}{|l|}{ Sodio $580 \mathrm{mg}$} & $24 \%$ \\
\hline \multicolumn{3}{|c|}{ Carbohidrato Total $29 g$} & $10 \%$ \\
\hline \multicolumn{3}{|c|}{ Fibra Dietética $I_{5}$} & \\
\hline \multicolumn{3}{|l|}{ Azucares 85 } & \\
\hline \multicolumn{3}{|l|}{ Proteina 96} & \\
\hline \multicolumn{3}{|l|}{ Vtsmina A } & $20 \%$ \\
\hline \multicolumn{3}{|l|}{ Vitsmina C } & $40 \%$ \\
\hline \multicolumn{3}{|l|}{ Calcio } & 466 \\
\hline \multicolumn{3}{|l|}{ Hierto } & $8 \%$ \\
\hline \multicolumn{4}{|c|}{ 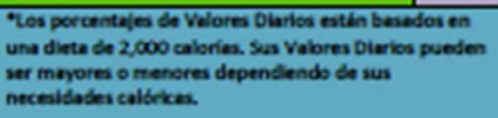 } \\
\hline & Calorias: & $\sqrt{2,000}$ & 2,500 \\
\hline Cosa Total & Nansa que & 65 & $80 x$ \\
\hline Cressat & Menos que & $20 x$ & 258 \\
\hline Colenterol & Manse que & $300 \mathrm{~ms}$ & $300 \mathrm{~ms}$ \\
\hline Sodlo & Mansa qua & $\begin{array}{l}2,400 \mathrm{~m} \\
\mathrm{x}\end{array}$ & $2,400 \mathrm{mg}$ \\
\hline Carb. Total & N menos & $300 x$ & $375 x$ \\
\hline IEra Detitica & N manos & $25 t$ & 308 \\
\hline
\end{tabular}

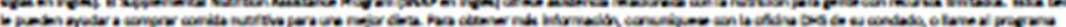

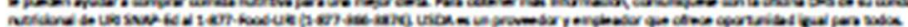



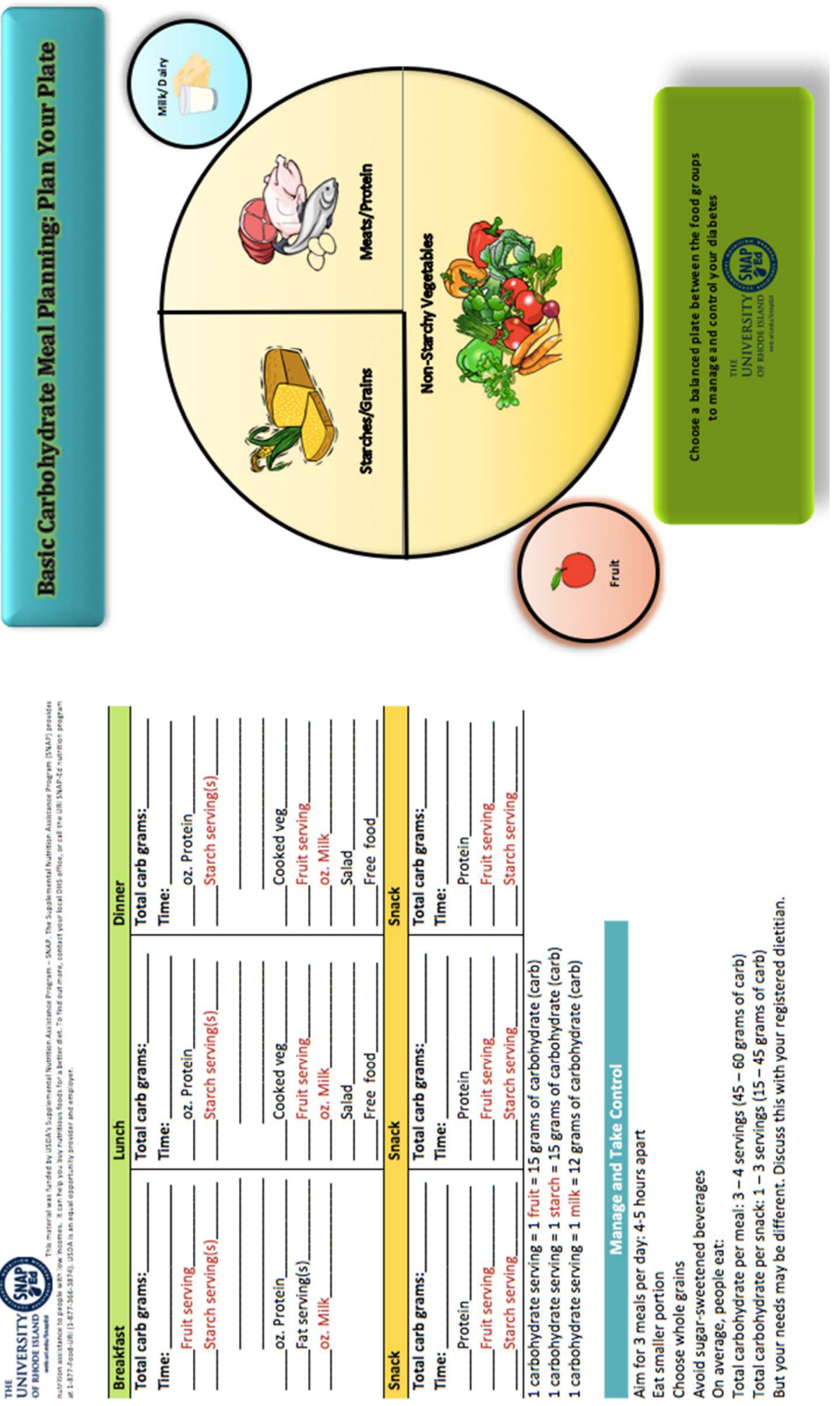


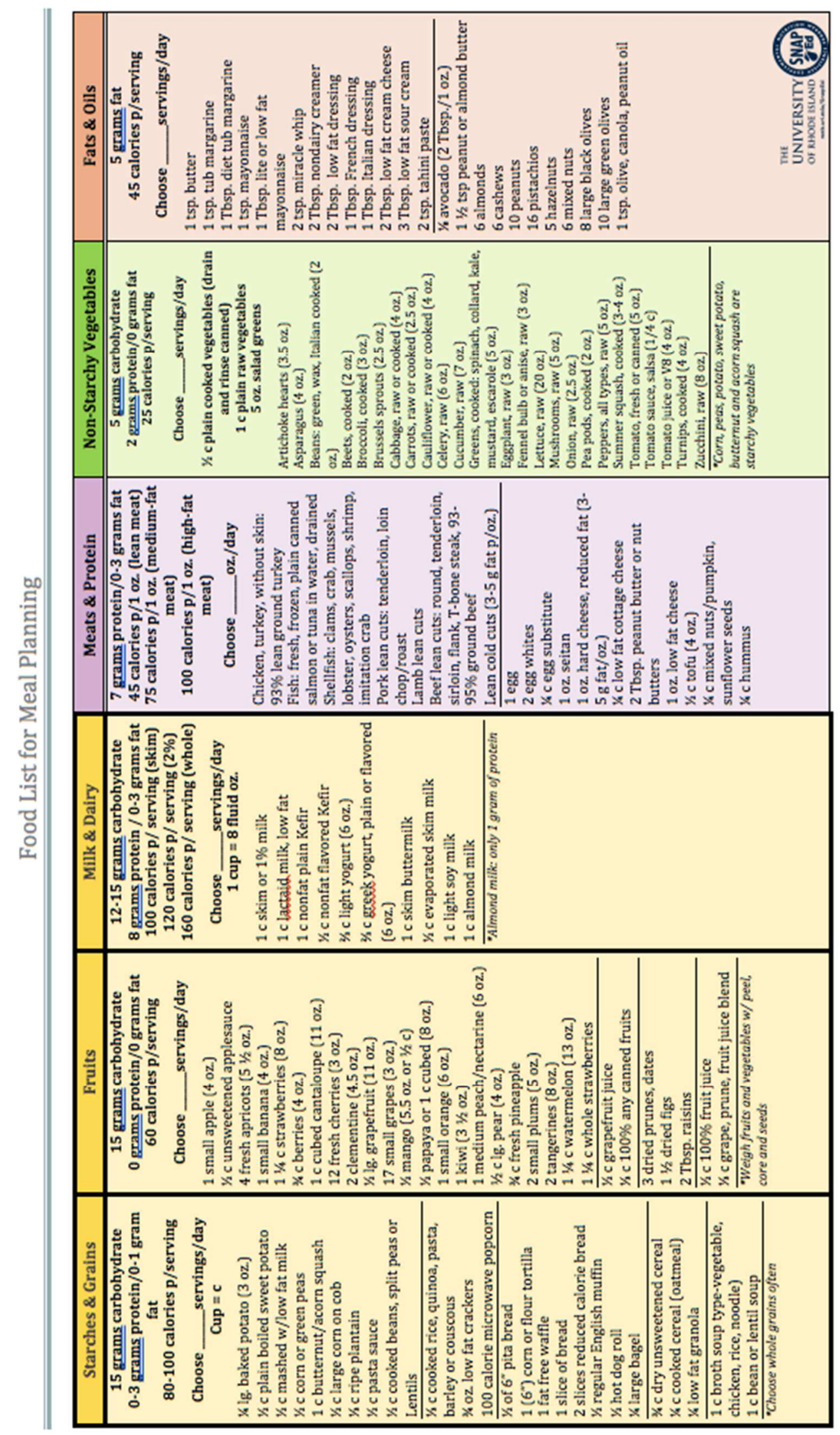




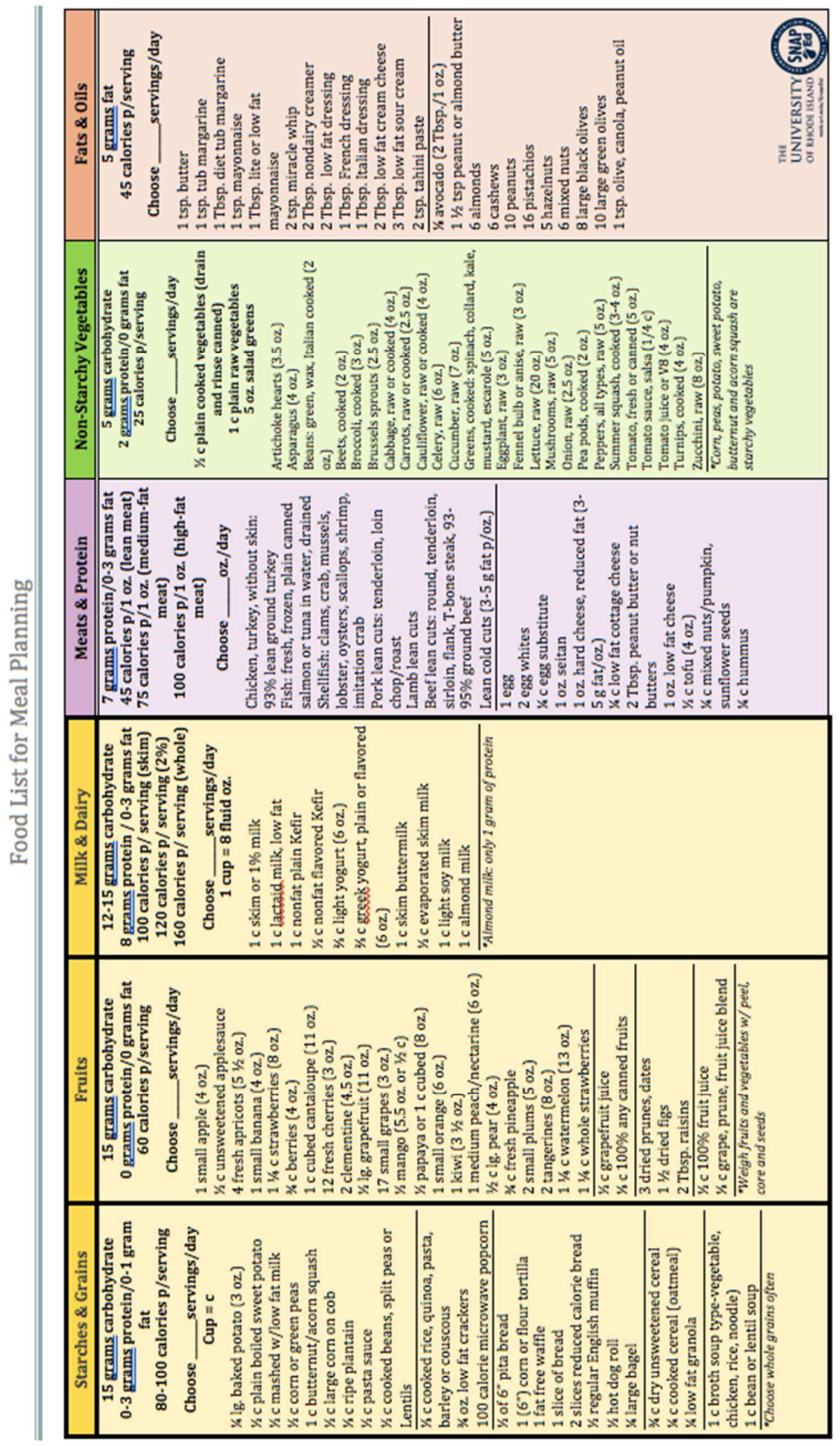




\section{APPENDIX J - LESSONS 1, 2, 3}

Lesson 1: USDA MyPlate/Five Food Groups/Introduction carbohydrate counting: $15 \mathrm{~g}=1$ serving

Nutrition Objectives:

- Students will be able to name all five food groups shown on the MyPlate poster

- Students will learn which food groups contain carbohydrates

- Students will learn that $15 \mathrm{~g}$ of carbohydrate $(\mathrm{CHO})$ is equal to $1 \mathrm{CHO}$ serving

Introduction:

- Introductions

- Purpose of the research study

- Complete Consent Form

- Complete Pre-Survey

- Begin asking students if they know about MyPlate and the name of the 5 food groups

USDA Myplate:

- Go over the USDA MyPlate board and the 5 food groups: grains, protein, vegetables (starchy vegetables), fruits and dairy

- Ask for example of foods for each food group: grains (tortilla, bread, pasta), starchy veggies (corn, peas), fruit (apple, banana) and dairy (yogurt and cheese)

- MyPlate is an example of what your dinner plate should look like

- Notice how each food group that we just mentioned is divided into sections of different sizes

- Why do you think some sections are bigger than others? (This shows how much of each food group should be at each meal)

- According to USDA MyPlate a healthy dinner plate should have half filled with fruits and vegetables. However, for diabetics we need to be aware that fruits have $\mathrm{CHO}$ as grains and dairy

- Put the board away and ask how many food groups are on the USDA Myplate: 5

- Ask according to USDA MyPlate half of the plate should be: fruits and vegetables

- Now that we know the 5 food groups, let's talk about carbohydrates

Intro to carbohydrate and which foods contain carbohydrates:

- What is carbohydrate (CHO): found in foods and is another word for sugars and the main source of energy for the body. CHOs get digested quickly and easily into glucose (sugar). CHOs are the foods that affect blood sugar the most

- Ask participants if they know which foods from the MyPlate contain CHOs.

- Foods that contain CHOs are: grains (rice, oatmeal, and barley), grain based (bread, cereal, pasta, crackers), starchy vegetables (potatoes, peas, corn) fruits and juices, milk and yogurt, dried beans (pinto beans, black beans), sweets and snacks (sodas, juice drinks, cake, cookies, candy, and chips), non-starchy vegetables like lettuce, cucumbers, broccoli, carrots, and cauliflower have a little $\mathrm{CHO}$ but in 
general are very low. Note: foods with less than $5 \mathrm{~g}$ of $\mathrm{CHO}$ per serving are considered free food

- Which food groups from the MyPlate contain CHO? Grains, starchy vegetables, fruits and dairy

Carbohydrate counting:

- Ask if they know what is $\mathrm{CHO}$ counting:

- $\mathrm{CHO}$ counting is a meal planning technique for managing the blood sugar levels. It helps to keep track of how much $\mathrm{CHO}$ you eat throughout the day. You set a limit for your maximum amount of carbohydrate to eat for a meal, and with the right balance of physical activity and medicine, if you need it, can help to keep your blood sugar levels in your target range

- How much carbohydrate you eat is very individual. Finding the right amount of carbohydrate depends on many things including how active you are and what, if any, medicines you take. Some people are active and can eat more carbohydrate. Others may need to have less carbohydrate to keep their blood glucose in control

- Say that 15 grams of $\mathrm{CHO}=1$ serving of $\mathrm{CHO}$ (show board)

- A place to start is at about 45-60 grams of carbohydrate at a meal that equals to 3 to $4 \mathrm{CHO}$ servings and 15 to 20 grams of $\mathrm{CHO}$ that equals 1 to $11 / 2 \mathrm{CHO}$ servings per snack (go over the board with meals)

- Ask: but how do we know the amount of CHO the foods have?

- Starting with food labels (Nutrition Facts Label) is a great way to know how much $\mathrm{CHO}$ is in a food

- For foods that do not have a label, you have to estimate how much $\mathrm{CHO}$ is in it

- Keeping general serving sizes in mind will help you estimate how much $\mathrm{CHO}$ you are eating

- Use a food scale, measuring cups and measuring spoon for foods without labels such as fruits and starchy vegetables

- Also use: fist $=1 \mathrm{cup}$, handful $=1-2 \mathrm{oz}$, thumb tip $=1$ teaspoon, thumb $=1 \mathrm{oz}$. or 1 tablespoon, palm $=3 \mathrm{oz}$. for woman and $5 \mathrm{oz}$. for men

- For example there is about 15 grams of $\mathrm{CHO}(1$ serving $)$ in:

- 1 small piece of fresh fruit $(4 \mathrm{oz}$.)

- $1 / 2$ cup of canned or frozen fruit

- 1 slice of bread ( $1 \mathrm{oz}$.) or 1 (6 inch) tortilla

- $1 / 2$ cup of oatmeal

- $1 / 3$ cup of pasta or rice

○ 4-6 crackers

- $1 / 2$ English muffin or hamburger bun

- $1 / 2$ cup of black beans or starchy vegetable

- $1 / 4$ of a large baked potato $(3 \mathrm{oz})$

- $2 / 3$ cup of plain fat-free yogurt or sweetened with sugar substitutes

- 2 small cookies

- 2-inch square brownie or cake without frosting

- 1/2-cup ice cream or sherbet

- 1 Tbsp. syrup, jams, jelly, sugar or honey

○ 2 Tbsp. light syrup 
○ 6 chicken nuggets

- 1/2 cup of casserole

- 1 cup of soup

- 1/4 serving of a medium French fry

- Ask how many grams of CHO equal 1 serving: $15 \mathrm{~g}$

- Ask how many grams of CHO you should have per meal: $45-60 \mathrm{~g}$

- Ask how many servings of CHO equals 45-60g of CHO? 3-4 servings

- Ask how many servings of CHO you should have per snack: $15-20 \mathrm{~g}$

- Ask how many serving of CHO equals 15-20g of CHO: 1-2 servings

- Ask do soda, tortilla and corn have CHOs? Yes, corn is a starchy vegetable with $\mathrm{CHO}$

- If time: Let's find the total CHO on the Nutrition Facts Label? Hand out the bag with labels and let's find the total $\mathrm{CHO}$ in each label

Handouts:

- ChooseMyPlate (SNAP-Ed English and Spanish)

- Nutrition Facts Label (SNAP-Ed English and Spanish)

- List of foods that contain CHO (English and Spanish)

Activities:

- Identify what foods from the 5 food groups contain $\mathrm{CHO}$

Program extender:

- USDA MyPlate (plastic)

Recipe:

- Yogurt parfait (pineapple tidbits/plain yogurt)

Materials to bring:

- Blue Folders with all handouts and forms

- Pens

- Pencils

- Markers

- Pre-surveys

- SNAP MyPlate board and food groups in English and Spanish

- SNAP MyPlate plastic plate

- Easel paper: 1 serving of $\mathrm{CHO}=15 \mathrm{~g}$ of $\mathrm{CHO}, 3-4$ servings $=45-60 \mathrm{~g}$ of $\mathrm{CHO}$

- Easel holders

- SNAP Nutrition Facts Label board

- Bag with Food Labels

- Blank papers

- Plastic USDA MyPlate for program extender

- Yogurt Parfait items and recipe: Spoons, cups, napkins, gloves, hair net, purel, plastic bag, paper towel 
Lesson 2: Nutrition Facts Label/Build a meal

Nutrition Objectives:

- Students will be able to read the Nutrition Facts Label

- Students will be able to count 45-60g of CHO per meal and 15-20g of CHO per snack

- Students will be able to build a meal with 45-60g of CHO using MyPlate

Introduction:

- Take attendance

- Review what did we learn last week:

$\circ$ MyPlate containing the 5 food groups

- Which food groups contain CHO: ask if grains, fruits, starchy vegetables like corn and peas, beans, yogurt, ice cream, regular soda, chicken and fish have $\mathrm{CHOs}$

○ Show the board: how many $\mathrm{CHO}$ we should eat per meal and snacks

- Today we are going to talk about food labels

Nutrition Facts Label:

- The label is intended to make it easier for you to use to make quick, informed food choices that contribute to a healthy diet specially finding the $\mathrm{CHO}$ amounts in foods

- For foods that come in packages, the best place to find the $\mathrm{CHO}$ is looking at the total $\mathrm{CHO}$ on the labels. The grams of total $\mathrm{CHO}$ on the label are the key to $\mathrm{CHO}$ counting. Don't worry about counting the sugar and fiber grams, as they are included in the total carb number

- Let's start reading a label, going over the SNAP label board:

○ First check the serving size: the information on the label is based on the serving size; different foods have different serving sizes and the number of servings in the package. Serving sizes are consistent to make it easier to compare similar foods; they are provided in units, such as cups or pieces, followed by the metric amount, e.g., the number of grams.

- Second check the serving per container: The size of the serving on the food package influences the number of all items on the label and all the nutrient amounts listed on the top part of the label. Pay attention to the serving size, especially how many servings there are in the food package. Say: "How many servings am I consuming"? (e.g., 1/2 serving, 1 serving, the whole thing).

- Now let's look at the total $\mathrm{CHO}$ : indicates the total amount of $\mathrm{CHO}$ in a serving of the product.

- If there are 2 servings in a box and you eat the 2 servings you have to multiply the $\mathrm{CHO}$ by 2

- Sugar: occurs naturally in foods such as fruit or come from refined added sugars sources such as table sugar or corn syrup.

- Lastly our friend fiber: found in fruits, vegetables, beans, nuts, seed and whole grains such as wheat bread. It is not digested in your intestines, which slows $\mathrm{CHO}$ digestion and glucose absorption, helping glucose not going up too fast. 
- Ask if you eat $30 \mathrm{~g}$ of potato how many servings of $\mathrm{CHO}$ do you eat? 2; why? Because 1 serving is equal to $15 \mathrm{~g}$ of $\mathrm{CHO}$

- If time: hand out labels and discuss the serving size, serving per container and total $\mathrm{CHOs}$

- From the food list from the handout, go over the food groups:

- Starch: breads, cereals, grains, starchy veggies, crackers, snacks, beans, peas, lentils $=15 \mathrm{~g} \mathrm{CHO}$ in 1 serving

- Fruit: $15 \mathrm{~g} \mathrm{CHO}=1$ serving. (it all depends on quantity, cups, amounts)

○ Dairy: milk, fat-free, low-fat, $1 \%$, reduced fat, $2 \%$, whole $=12 \mathrm{~g} \mathrm{CHO}$ in 1 serving

- Sweets, desserts, and other $\mathrm{CHO}=15 \mathrm{~g} \mathrm{CHO}$ in 1 serving

$\circ$ Non-starchy veggies $=5 \mathrm{~g}$ CHO in 1 serving (free food)

- Meat and meat substitutes: $0 \mathrm{~g}$ CHO in 1 serving; plant based proteins such as beans, or tofu, or soy beans: varies

- Fat: $0 \mathrm{~g} \mathrm{CHO}$

- Alcohol: varies

- Portion sizes count! Example a small apple: 15 g CHO, large apple: 30 g CHO.

- The use of food scale or measuring cups can help for foods without the label like fruits

- Remind 45-60 grams = 3-4 servings per meal is the approximate amount you need per meal: Breakfast, Lunch, Dinner and 15-20 grams $=1-2$ servings for snacks

- Activity:

$\circ$ Hand out MyPlate papers

- Using the handout containing a list of food groups and their amounts of CHOs, participants will build a meal or a snack writing their chosen foods in proper food groups on MyPlate

- Participants will count the total the amount of $\mathrm{CHO}$

- The meal should have between 45-60 g of CHO or 15-20 g of CHO for snack

Handouts:

- Nutrition Facts Label

- Food List

- Paper MyPlate

Activity:

- Build a meal and tally the $\mathrm{CHO}$ using food labels

Recipe:

- Cucumber and hummus

Incentive (program extender):

- Shopping list

Materials to bring:

- 3 easel stands: Total CHO amount in meals board, MyPlate board, NFL board 
- Paper MyPlate to build a meal

- Extra handouts from lesson 1

- Attendance sheet

- Pencils, pens, markers, calculators

- Recipe: hummus and cucumber

○ 4 oz. cups, spoons, napkins, gloves, hair net, purel, paper towel, hummus, cucumber, cutting board, knife

Lesson 3: review/build one meal/post survey/skill test/program evaluation

Nutrition Objectives:

- Students will be able to score $80 \%$ on the post survey

- Students will be able to score $80 \%$ on the skill of $\mathrm{CHO}$ counting and build a meal between 45-60 g of CHO using the USDA MyPlate

Introduction:

- Take attendance

- Today is our last day and we are going to do a quick review, following the post survey, build a meal and evaluations

- Let's recap:

- 5 food groups

- 3-4 servings of $\mathrm{CHO}=45-60 \mathrm{~g}$ of $\mathrm{CHO}$ per meal

- 1-2 servings of $\mathrm{CHO}=15-20 \mathrm{~g}$ of $\mathrm{CHO}$ per snack

CHO counting skill test: build a meal

- Hand out the USDA MyPlate

- Ask participants to pick a meal from breakfast, lunch or dinner (from plastic bags)

- Ask participants to build a meal placing the pictures containing total amount of CHO on the USA MyPlate

- Ask participants to count the total amount of $\mathrm{CHO}$, between 45-60g of CHO and write on the bottom on the page

Post survey:

- Ask participants to fill out the post survey; researcher will read the questions aloud to make sure participants understand questions.

Program Evaluation:

- Ask participants to complete the program evaluation

Recipe:

- Carrots and ranch dressing

Incentive (program extender):

- Vegetable peeler 
Materials to bring:

- Attendance

- $\mathrm{CHO}$ counting skill test

- Post survey

- Pens

- Pencils

- Incentives

- Salsa and whole grains tortillas 